\title{
Do inheritance rules affect voter turnout? Evidence from an Alpine region
}

\section{Andrea Bonoldi ${ }^{1} \cdot$ Chiara Dalle Nogare ${ }^{2} \cdot$ Martin Mosler $^{3} \cdot$ Niklas Potrafke $^{3}$}

Published online: 27 March 2020

(c) The Author(s) 2020

\begin{abstract}
We examine the relationship between inheritance rules and voter turnout. Inheritance rules are measured by entailed farms in South Tyrol: land properties whose inheritance is regulated by a law similar to the right of primogeniture. Using data for municipalities between 1998 and 2010, we show that voter turnout is high in municipalities with many entailed farms relative to population. The effect is based on local elections. If the number of entailed farms per 100 inhabitants increases by one standard deviation, voting turnout in municipal and provincial elections increases by around 1.27 and 1.43 percentage points (around 25 and $35 \%$ of a standard deviation). Our results suggest that entailed farm owners themselves are more likely to vote, and that entailed farms owners encourage other citizens of their municipality to participate in local elections.
\end{abstract}

Keywords Entailed farms · Voter turnout $\cdot$ Inheritance rules $\cdot$ Identity $\cdot$ Civic duty

JEL Classification $\cdot \mathrm{D} 72 \cdot \mathrm{K} 11 \cdot \mathrm{Q} 15 \cdot \mathrm{H} 70 \cdot \mathrm{Z19}$

Martin Mosler

mosler@ifo.de

Andrea Bonoldi

andrea.bonoldi@unitn.it

Chiara Dalle Nogare

chiara.dallenogare@unibs.it

Niklas Potrafke

potrafke@ifo.de

1 Department of Economics and Management, University of Trento, Via Inama, 5, 38122 Trento, Italy

2 Department of Economics and Management, University of Brescia, Via San Faustino 74/b, 25122 Brescia, Italy

3 Ifo Institute, Leibniz Institute for Economic Research, University of Munich, Poschingerstrasse 5, 81679 Munich, Germany 


\section{Introduction}

Since Downs (1957) formulated the paradox of voting, highlighting the incompatibility of rational behavior with voting when one's decision is not pivotal and voting is costly, many studies have investigated the paradox of voting [see the surveys by Geys (2006), and Cancela and Geys (2016)]. ${ }^{1}$ In fact, it is rather unlikely that the high voter turnout one observes in the real world is the consequence of irrational behavior. Aldrich (1993) proposed that the rationality of voting should be considered in the light of long-term political values and preferences, and Schuessler (2000) suggested the way out of the impasse by drawing from social theory and anthropology. We follow their suggestions and examine the determinants of voter turnout in a specific geographical context: South Tyrol, an Italian autonomous province on the border with Austria. Cultural traits have been shown to determine citizens' behaviour (Bisin and Verdier 2001). We investigate whether an aspect of culture, namely family types as measured by inheritance rules, predicts voter turnout in South Tyrol.

South Tyrol is a suitable environment to examine the nexus between inheritance rules and voter turnout. First, voter turnout has been high in South Tyrol: around $82 \%$ in municipal, $86 \%$ in provincial and $87 \%$ in national elections in the years 1998-2010. Up until the year 2010 a local party, the Südtiroler Volkspartei (SVP), dominated politics at all levels of government. Between 1998 and 2010, the SVP enjoyed a supermajority in almost all municipalities in South Tyrol and reached an average party vote share across the province of over $50 \%$ in all but three elections. ${ }^{2}$ Second, the South Tyrolean context is uniquely characterized by a legal institution called geschlossener Hof, whose origin is related to the historical evolution of South Tyrol and its German cultural background. A geschlossener Hof, or mountain entailed farm, is an impartible agricultural property which must be passed on to just one heir, usually the first son by the local tradition. The Italian law counterpart, rooted in the Roman law tradition, requires equal treatment of all siblings and empowers owners to partition their properties at will. Diverse inheritance rules are thus co-exisiting in the region. South Tyrolean municipalities are characterized by a varying proportion of families whose relationships are shaped by a selective inheritance rule or, in the words of Todd (1990), a different proportion of stem families.

We use data on the geographical distribution of entailed farms and examine whether the South Tyrolean municipalities with many entailed farms relative to population have a higher voter turnout over the period 1998-2010 than the municipalities with fewer entailed farms relative to population. The results show that a high concentration of entailed farms in a municipality is positively correlated with voter turnout in local elections. Voter turnout in municipal and provincial elections increases by around 1.27 and 1.43 percentage points (between a quarter and a third of a standard deviation) if the number of entailed farms per 100 inhabitants

\footnotetext{
1 New studies examine how electoral institutions such as compulsory voting, opening hours of polling stations and prepaid postage influence voter turnout (e.g. Garmann 2017; Hoffman et al. 2017; Schelker and Schneiter 2017; Bechtel et al. 2018; Gaebler et al. 2020; Potrafke and Roesel 2020).

2 Average SVP vote shares have constantly been below the 50 percent-threshold since 2010.
} 
increases by one standard deviation. Entailed farms relative to population are hardly correlated with voter turnout in national or European elections.

We discuss mechanisms that we consider to be likely to explain the positive correlation between the density of entailed farms and voter turnout. It is conceivable that the positive correlation between the number of entailed farms per 100 inhabitants and voter turnout relates to entailed farms owners' voting behavior. Sole heirs of entailed farms, properties with a high symbolic meaning, are more likely to attribute higher symbolic meanings to their own behavior, too, as if they were called to play a special role not just in the family, but also in the local community. The inheritance rule invests sole heirs with the awareness of being important for the persistence of a value system which they consider essential for their community. Under this hypothesis, altruism and a greater sense of civic duty may explain higher voter turnout of entailed farm owners (Jankowski 2002; Hamlin and Jennings 2011; Francois and Gergaud 2019). The size of the positive effect of entailed farms on voter turnout in local elections suggests that entailed farms owners encourage others in their municipality to vote, too. We recur to theories which relate voting to social pressure (Gerber et al. 2008) to explain the effect of entailed farms on the voting behavior of other citizens in the community.

The paper is organized as follows: in Sect. 2 we discuss how our study relates to previous studies; in Sect. 3 we present the South Tyrolean political and economic context, and the role of entailed farms; in Sect. 4 we describe our dataset; in Sect. 5 we present our model; in Sect. 6 we discuss our main results; Sect. 7 includes robustness checks; and Sect. 8 concludes.

\section{Cultural norms, family types and voting behavior}

Many anthropologists, historians and demographers consider inheritance rules as influential drivers of social developments (see, for example, Grandits and Heady 2003). Economists have investigated the role of inheritance rules, too. Some scholars have focused on the effect inheritance rules have on wealth distribution and accumulation (see, for example, De Nardi 2004; Behrman and Rosenzweig 2004). Other studies suggest that inheritance rules may be relevant for individual decisions through the moderating role of family relations, and are embedded in the literature that investigates cultural transmission (see, for example, Bisin and Verdier 2001). The nature and strength of family ties are persistent cultural traits, and have been shown to causally determine preferences (Galasso and Profeta 2018), economically relevant behavior (Alesina and Giuliano 2010) and political participation (Alesina and Giuliano 2011).

The association between family types and prevailing inheritance rules dates back to the origin of economics as a science: Smith and Mill (Baker and Miceli 2005) and Ricardo (1821) mentioned them. More recently, Todd's (1990) classification of European regions according to the prevailing family type, where the type strongly depends on the local inheritance rule, has been used to discuss the effects of family types on socio-economic outcomes such as social capital. Scholars examine whether the family substitutes or complements social capital, and which family types are 
associated with higher levels of social capital. For example, Duranton et al. (2009) show that regions with higher levels of social capital have a lower prevalence of either nuclear family types, which have egalitarian inheritance rules, or stem families, which have selective inheritance rules. Dilli (2016) examines the relation between family systems and levels of democracy on a national scale, concluding that countries that have experienced a greater incidence of families with high testamentary freedom have higher levels of democracy in the long run. Broms and Kokkonen (2019), however, find that regions that have practised selective inheritance rules are characterised by a higher perceived institutional quality, which has been shown to positively correlate with voter turnout (Sundström and Stockemer 2015). The limitations of these studies are twofold. On the one hand, the variables of interest are usually discrete: the family types are represented in the models by dummy variables. Different degrees of prevalence of family types are not captured. On the other hand, the degrees of freedom are limited if many family-type dummy variables and control variables for the national and continental institutional context are included.

We contribute to the literature on family types and social capital by examining a single European region with a common institutional setting, but intra-regional heterogeneity regarding selective and egalitarian inheritance rules. Our variable of interest is continuous: the share of families adopting a selective inheritance rule relative to the population in each municipality. The distinction between the degree of testamentary selectivity is an important feature of inheritance rules. A classic in ethnography confirms the relevance of testamentary selectivity: "The Hidden Frontier" (Cole and Wolf 1974) which is based on an anthropological field study set in South Tyrol in the late 1960s. Cole and Wolf (1974) investigated the differences in behavior and social interaction between the inhabitants of two contiguous villages, German-speaking St. Felix in South Tyrol and Italian-speaking Tret, part of the neighboring Trento province. The authors conclude that many of the observed differences can be related to the distinct ways property was transmitted from one generation to the other. We build on their observations and examine how the selective inheritance rule associated with entailed farms relates to voter turnout.

\section{South Tyrol: political context and entailed farms}

\subsection{Political, cultural and economic context}

South Tyrol, the northernmost province of Italy, enjoys a special regime of political autonomy, based on its linguistic diversity and historical experience (Steininger 2003). In the early Middle Ages people of German origin migrated to this mountainous area, while native speakers of the Rhaeto-Roman Ladin language remained confined in few valleys. Since 1363 up until World War I South Tyrol was part of the Habsburg territories, and was only subsequently annexed by Italy. Soon after taking power, the fascist regime in Italy tried to italianize the land through a restriction of the rights of the German-speaking population and promoted immigration from other Italian provinces. At the end of World War II, the 1946 Paris Agreement between Austria, Italy and the victorious powers stated that South Tyrol would remain a part 
of Italy, but it ensured a high degree of self-governance and protected the cultural identity of the German-speaking population. Nowadays, some $63 \%$ of the population belongs to the German linguistic group, $23 \%$ to the Italian one, $4 \%$ to the Ladin minority, and $10 \%$ to other groups according to the 2011 census (ASTAT 2017). The Italian-speaking population is concentrated almost exclusively in the major urban centers, and in particular in the Bolzano/Bozen metropolitan area.

Since South Tyrol is an autonomous province of Italy, the role of the central government is limited and the provincial government is responsible for health-, schooland infrastructure-related policies. Periodically, a redefinition of competences attributed to the local government is implemented after bargaining agreements between the central and provincial government. Since the end of World War II, the province has been ruled by the Südtiroler Volkspartei (SVP), ${ }^{3}$ a centrist and Catholic-inspired party representing the German-speaking population and until recently supported by large majorities at the elections. A strong separation between language groups, with the aim of maintaining the unique characteristics of the German-speaking population, has been pursued especially through cultural and educational policies. Assignments of jobs in the public administration and of public resources are defined according to the relative weight of the linguistic groups.

In 1951, South Tyrol took the 57th place regarding per capita GDP among the 92 Italian provinces, with a population mainly employed in agriculture. ${ }^{4}$ Nowadays, South Tyrol is the second wealthiest Italian province as measured by GDP per capita (Eurostat 2017) and agriculture only contributes some $4 \%$ to the value added in the province (ISTAT 2017). Because of the important role in society in the past, however, the agricultural sector still enjoys wide esteem by the local population who considers farmers as the traditional guardians of cultural identity and associates farmers with ecological tasks in the mountain territory (Vogel et al. 2009).

Historically, farmers have played a peculiar role in local politics. Since the 15 th century, South Tyrolean peasantry has enjoyed a privileged position compared to farmers in other parts of the Habsburg monarchy (and most of Europe, in fact). South Tyrolean peasants were relatively educated ${ }^{5}$ and had their own representatives in the provincial Diet (a deliberative assembly) as well as clergy, aristocracy and the city (Kofler 1985). Even in more recent times the farming community in South Tyrol has expressed a strong political representation.

\footnotetext{
3 The Autonomous Statute ensures that both linguistic groups are represented in the provincial government. The SVP has always formed governments with one party representing the Italian minority. The second party has always had a minor role.

4 Successive developments were the result of a mix of external factors: increasing demand for high quality agricultural products and for tourism, the development of the road and rail Brenner axis, and local policies which have been financed by the considerable fiscal resources due to the autonomy status (Leonardi 2009; Bonoldi 2009).

5 In South Tyrol, primary education became mandatory in 1774 following the introduction of the "Allgemeine Schulordnung" by empress Maria Theresa (Augschöll 2004).
} 


\subsection{Entailed farms}

South Tyrol has a legal institution that is unique in the Italian legislation: the entailed farm (Mori and Hintner 2013; Poggeschi 2008). The term identifies a farm which, at the death of the owner, is not divided among the descendants but transmitted to only one heir, usually one of the children. The other family members are only entitled to a small compensation not proportional to the value of the land. Sustainability in the Alpine conditions has been a major motivation for establishing entailed farms. Entailed farms are more present at higher altitudes and where breeding is a major source of income (Bätzing 2003; Schennach 2003). In such a demanding mountainous environment, an entailed farm has ensured enough income to support a family over many generations and prevented excessive partitioning, which would have otherwise lead to abandoning the mountains. In modern times, most of the noninheriting descendants do not stay at the farm as subordinates, as it once used to be, ${ }^{6}$ but they pursue different careers, often in the service industry.

Without special authorization, the owner of an entailed farm cannot dispose of the property which means that the farm is transmitted as a whole. The regulatory exception to the principles of Italian private law, i.e. equal treatment of co-heirs and freedom to partition properties, is possible due to the autonomous status that South Tyrol enjoys and is the result of a historical evolution. The origins of the selective inheritance rule can be found in the Germanic law which in some areas favored the rights of the family over those of individuals (Mori and Hintner 2013). ${ }^{7}$ In addition to ethno-cultural factors, the development of entailed farm can also be explained by the structure of property rights in the Middle Ages and the access to non-agricultural activities (Schennach 2003). In the late Middle Ages entailed farms were present almost exclusively in the German-speaking areas of the Alps. In South Tyrol, historical events have later favored the enlargement of the area inhabited by the German-speaking population, which has weakened the relationship between language and inheritance rules.

In the fascist period, the imposition of the Italian legal framework in 1929 meant that entailed farms formally disappeared, but most entailed farms kept being run according to the old tradition. In fact, out of the about 11,000 entailed farms recorded in 1929, only $6 \%$ had dissolved in 1954, when the provincial government restored the historic inheritance rule for those properties that had been entailed farms before $1929 .{ }^{8}$ Nowadays, about two thirds of farms in South Tyrol are entailed farms.

\footnotetext{
${ }^{6}$ In the old times, social norms imposed that the siblings who did not inherit would stay at the farm as their brother's servants and could not marry. The effect of the inheritance rule combined with this marriage norm allowed mountain agriculture to be sustainable even when productivity was low (Grandits 2003).

${ }^{7}$ South Tyrolean entailed farms were formalized with ad-hoc regulations in 1770, 1795 and 1900.

${ }^{8}$ The matter is currently regulated by a provincial law which has been in force since 2001 .
} 


\subsection{Entailed farm owners and voting behavior}

We propose that the selective inheritance rule (and not agricultural firms per se), as measured by a high density of entailed farms in a South Tyrolean municipality, is associated with a high voter turnout. We believe that the behavior of entailed farms owners, who themselves vote more often than other community members and may even encourage others to vote, drives the effect. Two mechanisms are plausible explanations why municipalities with more entailed farms relative to the population have higher voter turnout.

A first argument relates to altruism as suggested by Jankowski (2002). Because of their historical tradition, entailed farm owners may feel that they play a prominent role not just in the family, but also in their municipalities. Under this hypothesis, sole heirs of entailed farms pay more attention to the welfare of their community (or what they believe is its welfare) than the average community member. There are survey data specifically focusing on South Tyrolean mountain farmers, most of whom are entailed farm owners (Vogel et al. 2007, 2009). The survey is based on a stratified sample of 343 South Tyrolean mountain farmers and measures farmers' perception of the importance of their role as producers of positive externalities. Out of the nine suggested non-commodity productions, "maintenance of traditional culture" ranked second in perceived importance, preceded only by "preservation and maintenance of landscape", arguably pertaining to the cultural domain, too. ${ }^{9}$ Vogel et al. $(2007,2009)$ maintain that the high ranking of these tasks in mountain farmers' self-valuation relates to their feeling of being essential for the value system, and that they consider themselves as the "guardians" of their community. ${ }^{10}$ Generally, the autonomy status ensures a high degree of legislative competencies at the local level in South Tyrol. Thus, we expect a high voter turnout in municipal and provincial elections if altruism explains the voting behaviour of entailed farm owners.

Second, it may well be that the selectivity of the inheritance rule induces a high sense of civic duty. Owners of entailed farms are then more likely to vote than citizens with other professions because they derive utility from the act of voting per se (Geys 2006) or from the confirmation of their "special" identity (Hamlin and Jennings 2011). In the first case, we would expect that voter turnout of entailed farm owners does not differ between elections. In the second case, the salience of the elections, as perceived both by the entailed farms owner and their community, matters: the sense of identity confirmation would be higher in more relevant elections.

Owners of entailed farms may also encourage others in their municipality to actively participate in elections if they indeed see themselves as "guardians of the community" or want to confirm their identity. Gerber et al. (2008) use a field experiment to show that social pressure is an important driver of voting behaviour. They

\footnotetext{
${ }^{9}$ Landscape is itself an essentially cultural notion, as opposed to environment (Settis 2012). The survey also asked mountain farmers to consider their role in environmental protection. Apart from the high selfappreciation as safeguards against natural disasters, all other functions related to environment were much less answered with the "very important" option.

${ }^{10}$ On perceived identity, see Hillman (2010).
} 


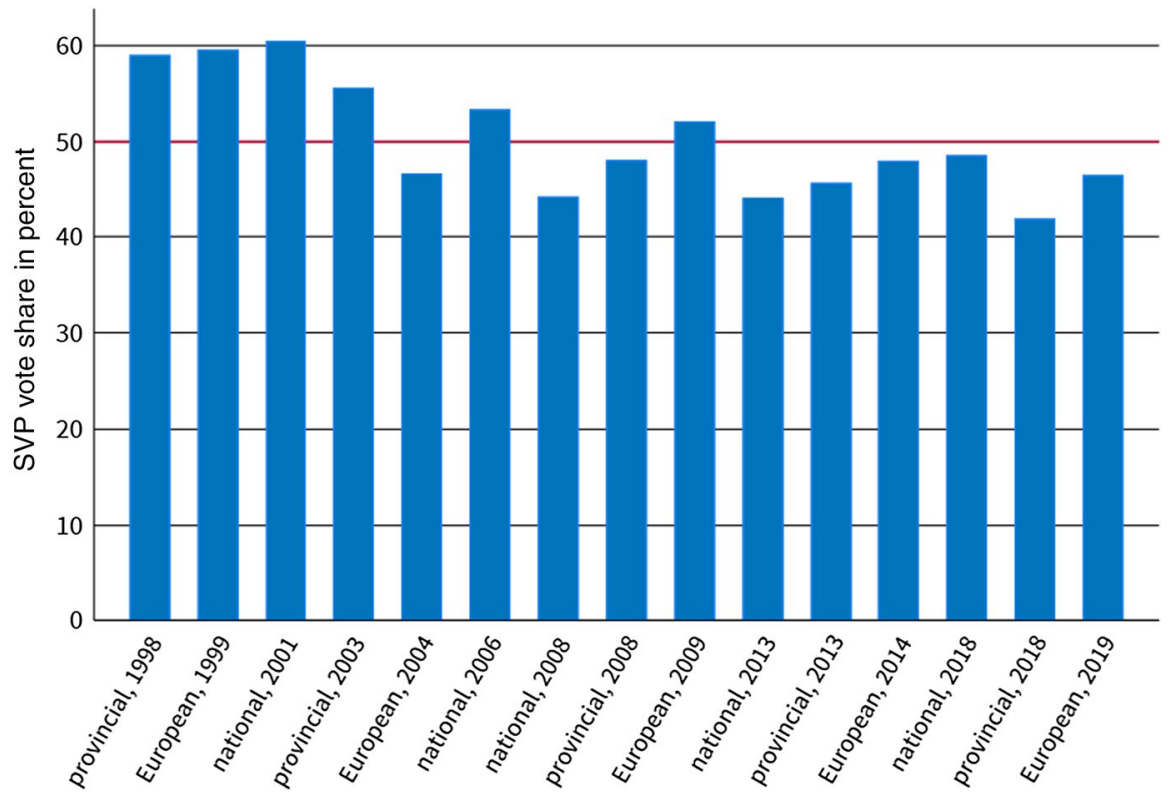

Fig. 1 Vote share of the Südtiroler Volkspartei (SVP) in South Tyrol between 1998 and 2019

argue that an agent's utility depends on other agents' opinion about her after observing her voting behaviour, given that voting is commonly valued as good. If we assume that the owners of entailed farms play a prominent role in local communities, we can expect that social pressure on community members who are not entailed farms owners is greater the higher the number of entailed farms in a municipality. Overall, the effect of entailed farms on voter turnout should be larger than the share of owners of entailed farms in the electorate would imply.

\section{Data and descriptive statistics}

We use voter turnout at each of the 116 municipalities in South Tyrol, and examine four election types between 1998 and 2010. ${ }^{11}$ We focus on a period in which individual votes were highly unlikely to be pivotal because the largest party, the SVP, regularly received a supermajority. Political circumstances changed after 2010: the predominant SVP lost part of its electoral support and received on average less than $50 \%$ of the votes. Figure 1 shows the average vote share of the SVP in South Tyrol for elections since 1998.

\footnotetext{
11 There were no municipal elections in the municipalities of Bronzolo/Branzoll, Campo di Trens/ Freienfeld and Laives/Leifers in 2000, in Valdaora/Olang in 2005, and in Badia/Abtei, Brennero/Brenner, Malles/Mals, Plaus and Velturno/Feldthurns in 2010.
} 


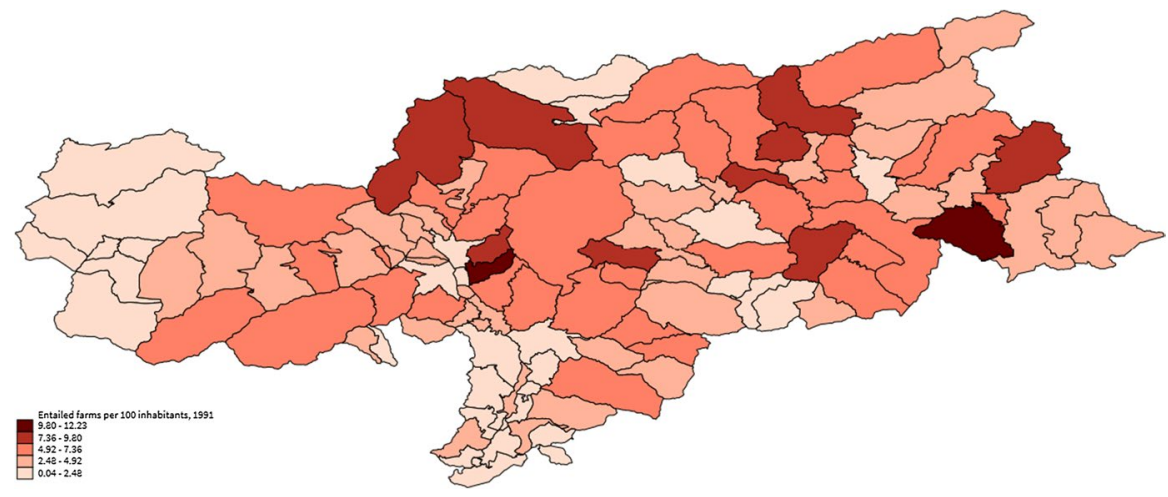

Fig. 2 Entailed farms per 100 inhabitants in 1991 by municipality

Voter turnout in South Tyrolean municipalities has been high compared to the average voter turnout in Italy and to voter turnouts of other European countries. ${ }^{12}$ For example, the average voter turnout for national elections in South Tyrolean municipalities was between 85.6 and $88.5 \%$ in our sample period (compared to the Italian average of 80.5 and $83.6 \%$ ) and between 63.3 and $75.5 \%$ in the elections to the European Parliament (compared to 43.0 and $49.5 \%$ at the European level). The variation of voter turnout across municipalities is comparatively low. Nevertheless, voter turnout in the European elections is much lower than voter turnout in national, provincial and municipal elections, indicating that voters well distinguish between the types of elections.

We use data on entailed farms in each municipality in the year 1991 to predict voter turnout over the period 1998-2010. The data on entailed farms have been compiled by Schuler (1992). For reference, in $200980.8 \%$ of the entailed farms were owned by a single person, and only $1.8 \%$ were owned by companies, the Catholic Church or other collective entities (Mori and Hintner 2009). ${ }^{13}$ Though the corresponding 1991 data are not available, we do not find evidence that proportions have changed much over time. There were some 11,500 entailed farms in South Tyrol in 1991 , out of a population of about 458,500 . An entailed farm is generally owned by just one person. In that case, entailed farm owners constitute on average $4.1 \%$ of the electoral body in South Tyrol (i.e. of those aged 18 and above).

The number of entailed farms per 100 inhabitants varies across the municipalities in South Tyrol (Fig. 2). The main reason for this variance is the difference in the absolute number of entailed farms between municipalities rather than the difference in inhabitants: South Tyrolean municipalities had between 1 to 376 entailed farms in 1991. In particular, Venosta/Vinschgau at the Northwestern part of the province

\footnotetext{
12 Compulsory voting laws are the same in South Tyrol and the rest of Italy.

$1317.3 \%$ of entailed farms are owned by more than one person. Mori and Hintner (2009) describe that an entailed farm may temporarily have more than one owner if the transmission of property through succession is still ongoing. The bureaucratic inheritance process after the previous owners died may take up to several years.
} 
and the municipalities around Bolzano/Bozen in the Adige/Etsch valley have had, on average, fewer entailed farms, which relates to the history of these areas: Venosta/ Vinschgau, on the border with Switzerland, was a Ladin-speaking area up until the seventeenth century. The villages in the Adige/Etsch valley, where the land is less steep and more fertile, developed an economy based on the production of fruits and wine and on trade as early as the nineteenth century, meaning that it was less necessary preserve land property from fractionalization. ${ }^{14}$

The number of entailed farms has slightly varied over the years since the re-introduction of the institution in 1954 because according to the modern law an entailed farm can be dissolved, partitioned into two or be newly established under certain conditions and upon request. In the last years the number of entailed farms has increased constantly, though modestly. There are special bureaucratic commissions at the local level that consider these requests and decide according to the detailed guidelines regulating the issue. The number of requests to modify the legal status of a farm, however, is small (20-40 cases every year) with respect to the total number of entailed farms. There is no strong incentive to dissolve entailed farms, because the owner cannot dispose of the land freely: the land of the entailed farm may be sold only to other entailed farms nearby. Property owners also enjoy special credit conditions since the re-introduction of the institution in 1954 (justified by the fact that they must pay their siblings a small compensation) and looser restrictions regarding maximal building cubage (Provincia Autonoma di Bolzano Alto Adige 1997). ${ }^{15}$ Splitting an entailed farm in two farms is only possible in the case that each of the two new farms can guarantee income for four adult people. The creation of a second entailed farm is rather unlikely because the original farm would need to be highly productive (Mori and Hintner 2013). Finally, transforming property into a new entailed farm means a permanent change from an egalitarian to the selective inheritance rule. This change is likely to trigger dissonances within the family, thus discouraging potential beneficiaries to establish an entailed farm. Most entailed farms are therefore old institutions.

We also use historical data on the distribution of entailed farms in 1929, which were compiled by Agostini (1962) as a robustness check. ${ }^{16}$ The correlation coefficient between the number of entailed farms in each municipality in 1929 and 1991 is 0.97. Before 1929 public policies favoring entailed farm owners did not exist, hence there were few incentives to transform a farm into an entailed one. One might argue that improvements in land productivity over time in certain areas of South Tyrol may have favored the possibility to split entailed farms, which would make the number of

\footnotetext{
14 The small clusters of villages of the valleys in the southeastern part of the province also have a lower proportion of geschlossene Höfe. This is the area where most people speak Ladin. Of the two Ladin valleys, however, only one (Gardena/Gröden) seems to be associated with less entailed farms, confirming the hypothesis that not only culture, but also ecology had a role in determining the success of the institution (Cole and Wolf 1974).

15 Some entailed farms have become holiday farmhouses in the last decades.

16 The 1929 data is only available for 89 of the 116 municipalities in South Tyrol. This is because 13 municipalities on the southern border belonged to the neighbouring province of Trento at that time, and 14 smaller municipalities had been merged with each other two by two.
} 
farms dependent on variables which may also affect voting behavior today. Yet this link is rather unlikely. Indeed, land productivity rapidly increased during the last decade before World War I (Leonardi 1996), but this development happened almost exclusively in the Adige/Etsch valley, the flattest part of South Tyrol where entailed farms were rare. Instead, entailed farms have been typical for mountain farming, which remained subsistence farming with little use of machinery for an extended period after 1929.

\section{Empirical strategy}

We estimate the following cross-sectional baseline model to examine the correlation between voter turnout and entailed farms relative to population:

$$
y_{i}=\alpha \operatorname{Farms}_{1991, i}+\beta X_{i}+\mu_{d}+\varepsilon_{i}
$$

where $y$ is our dependent variable, voter turnout, in municipality $i$ with $i=1, \ldots$, 116. Farms describes the number of entailed farms per 100 inhabitants in 1991 in each municipality. $X$ is a set of control variables. $\mu$ are fixed effects for each district $d=1, \ldots, 7$, and $\varepsilon$ is the error term. We estimate the model by ordinary least squares (OLS) with robust standard errors.

We employ the following interaction model as a second specification to examine whether the effect of entailed farms per 100 inhabitants on voter turnout differs between the four types of elections:

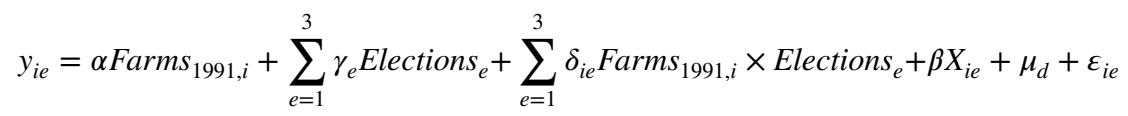

where Elections are dummy variables for each election type $e=1, \ldots, 3$ taking the value 1 if the election was at the municipal, national or European level, and 0 otherwise. Provincial elections are the reference category. We use an OLS model and cluster standard errors at the municipality level in this specification.

In both model specifications, the dependent variable, voter turnout, and the control variables are measured as averages over each election type. The full sample over the period 1998-2010, including 3 elections of each type, and a sub-sample of the most recent elections over the period 2008-2010, which includes a single election of each type, are used for our estimations.

Reverse causality between the number of entailed farms in 1991 and voter turnout over the sample period starting in 1998 can be ruled out. To deal with potential omitted variable bias, we include control variables in the vector $X$ that are likely to predict voter turnout and are correlated with the number of entailed farms. Altitude above seal-level in meters, measured as the average over each municipality, is positively correlated with the number of entailed farms relative to population and with the difference between the highest and the lowest geographical point in the municipality, where a steep environment makes shoe leather costs higher. Surface in square kilometers accounts for shoe leather costs which matter because the dispersion of 
houses within a municipality is likely to be correlated with the number of entailed farms per 100 inhabitants. The larger the surface of a municipality, the more time consuming it is to go to the ballot box which is often located close to the center of a municipality (e.g. in the city hall). By controlling for the number of agricultural firms per 100 inhabitants we can distinguish between the influence of the agricultural sector per se and the effect of the legal inheritance rule on voting behavior. Generally, farmers have been shown to be quite active in participating in elections (e.g. Martikainen et al. 2005). The number of agricultural firms per 100 inhabitants is positively correlated with the number of entailed farms per 100 inhabitants. The share of commons relates to community land properties of Medieval origin which are still present in South Tyrol and represent a relevant share of all properties (Casari 2007; Casari and Lisciandra 2016). In most cases these lands are high mountain pastures. ${ }^{17}$ This variable is also positively correlated with entailed farms relative to population. Population captures potential peer effects, which have been shown to matter in communities in another Alpine country, namely Switzerland (Funk 2010). Voter turnout is usually pronounced in small municipalities because citizens may observe and comment on neighbors' participation in elections. By construction, the number of entailed farms relative to population is large, ceteris paribus, when population is small. The share of population aged 65 and above accounts for the possible difference in the voting behavior of the elderly. The share of population aged 65 and above is positively correlated with the number of entailed farms per 100 inhabitants. We use the share of the German-speaking population relative to total municipal population as an additional control variable. Since 1981, the inhabitants of South Tyrol were asked to answer an extra question in the national censuses on their (feeling of) belonging to either linguistic group. ${ }^{18}$ The share of the German-speaking population is included to proxy cultural and institutional characteristics common to municipalities with a Germanic tradition, and hence disentangles the effect of these historic factors from the effect of the legal inheritance rule of entailed farms. We include the share of high school graduates relative to the total population in 2001 as a proxy for the level of education as an additional control variable. To disentangle the influence of a specific inheritance rule and the level of social or civic capital, we include the share of volunteers relative to total population. In fact, South Tyrol ranks comparatively high in Italian regions' social capital and human development indices. The correlation between the entailed farms in 1991 relative to population and the share of volunteers over population in $2011^{19}$ is positive. We consider yearly data on the number of hotel beds per capita as an explanatory variable to proxy for the entrepreneurial vocation of a municipality, given that tourism is an important economic activity, and for the possible influence of foreign visitors on voting

\footnotetext{
17 While the data only covers the year 2010, these properties hardly vary in size over time.

18 This extra question of the census, called "linguistic census", is a controversial issue in local politics (Poggeschi and Lantschner 2008). Some question that the answers are sincere, and there is possibly an overestimation of the declaration to be part of the German-speaking group.

19 The number of volunteers at the municipal level is only available for the year 2011 (ASTAT 2017). We contacted a main volunteer organisation of the area, UVF (volunteer fire fighters association). They confirmed that the numbers vary little from one year to the next.
} 
Table 1 Summary statistics

\begin{tabular}{|c|c|c|c|c|c|}
\hline Variable & Observations & Mean & SD & Min & Max \\
\hline Voter turnout, elections between 1998 and 2010 & 1383 & 81.43 & 8.24 & 48.82 & 94.70 \\
\hline $\begin{array}{l}\text { Voter turnout, municipal elections between } 1998 \text { and } \\
2010\end{array}$ & 339 & 82.42 & 4.97 & 63.80 & 91.80 \\
\hline $\begin{array}{l}\text { Voter turnout, provincial elections between } 1998 \text { and } \\
2010\end{array}$ & 348 & 85.97 & 4.12 & 69.10 & 94.70 \\
\hline $\begin{array}{l}\text { Voter turnout, national elections between } 1998 \text { and } \\
2010\end{array}$ & 348 & 86.69 & 3.14 & 71.72 & 92.93 \\
\hline $\begin{array}{l}\text { Voter turnout, European elections between } 1998 \text { and } \\
2010\end{array}$ & 348 & 70.69 & 7.38 & 48.82 & 86.10 \\
\hline Voter turnout, elections between 2008 and 2010 & 459 & 78.21 & 10.02 & 48.82 & 91.22 \\
\hline Voter turnout, municipal election in 2010 & 111 & 79.79 & 5.10 & 63.80 & 90.40 \\
\hline Voter turnout, provincial election in 2008 & 116 & 84.24 & 4.37 & 69.10 & 91.10 \\
\hline Voter turnout, national election in 2008 & 116 & 85.57 & 2.65 & 78.20 & 91.22 \\
\hline Voter turnout, European election in 2009 & 116 & 63.32 & 5.60 & 48.82 & 76.25 \\
\hline Entailed farms per 100 inhabitants, in 1991 & 116 & 4.19 & 2.43 & 0.04 & 12.23 \\
\hline Altitude above sea-level, in meters & 116 & 849.71 & 380.95 & 212 & 1568 \\
\hline Surface area, in square kilometers & 116 & 63.78 & 57.59 & 1.63 & 302.27 \\
\hline Agricultural firms per 100 inhabitants & 1383 & 6.50 & 3.33 & 0.46 & 18.52 \\
\hline Share of commons & 116 & 0.17 & 0.20 & 0.00 & 0.84 \\
\hline Population, divided by 100 & 1383 & 41.46 & 98.61 & 1.73 & 1039.2 \\
\hline Share of population aged 65 and above & 1383 & 0.15 & 0.03 & 0.07 & 0.24 \\
\hline Share of German speaking population & 232 & 84.13 & 26.16 & 1.53 & 100.00 \\
\hline Share of high school graduates & 116 & 18.55 & 4.64 & 7.41 & 31.27 \\
\hline Share of volunteers & 116 & 0.32 & 0.14 & 0.08 & 0.91 \\
\hline Number of hotel beds per capita & 1383 & 0.48 & 0.55 & 0.00 & 4.34 \\
\hline Income per capita, in logarithms & 459 & 9.48 & 0.16 & 8.91 & 9.97 \\
\hline Rain on date of election, in millimeters & 1372 & 2.55 & 4.93 & 0.00 & 24.80 \\
\hline Valid votes relative to total votes & 696 & 90.01 & 4.49 & 69.58 & 99.14 \\
\hline Entailed farms per 100 inhabitants, in 1929 & 89 & 6.01 & 3.38 & 0.06 & 14.07 \\
\hline
\end{tabular}

behavior. Finally, we include the logarithm of income per capita, which is available for the years after 2007 and measures the average taxable income per capita in each municipality, for the sub-sample of the elections over the period 2008-2010. Higher-income citizens are usually more likely to participate in elections than lowerincome citizens, ${ }^{20}$ and the number of entailed farms relative to population is positively correlated with income per capita. Table 1 shows the summary statistics for voter turnout and the independent variables at the municipal level.

\footnotetext{
${ }^{20}$ On the extent to which income per capita predicts voter turnout, see Cancela and Geys (2016) and Geys (2006).
} 
Table 2 Voter turnout in South Tyrolean municipalities, average over all elections between 1998 and 2010

\begin{tabular}{|c|c|c|c|c|}
\hline & (1) & (2) & (3) & (4) \\
\hline Entailed farms per 100 inhabitants in 1991 & $\begin{array}{l}0.5682 * * * \\
(0.1481)\end{array}$ & $\begin{array}{l}0.5413 * * * \\
(0.1485)\end{array}$ & $\begin{array}{l}0.3526^{*} \\
(0.2010)\end{array}$ & $\begin{array}{l}0.3048 * \\
(0.1667)\end{array}$ \\
\hline Altitude above sea-level, in meters & & $\begin{array}{l}0.0007 \\
(0.0008)\end{array}$ & $\begin{array}{l}-0.0008 \\
(0.0010)\end{array}$ & $\begin{array}{l}-0.0000 \\
(0.0009)\end{array}$ \\
\hline Surface area, in square kilometers & & $\begin{array}{l}-0.0099 \\
(0.0060)\end{array}$ & $\begin{array}{l}-0.0087 \\
(0.0059)\end{array}$ & $\begin{array}{l}-0.0012 \\
(0.0043)\end{array}$ \\
\hline $\begin{array}{l}\text { Average of agricultural firms per } 100 \\
\text { inhabitants }\end{array}$ & & $\begin{array}{l}0.2083 * * \\
(0.0797)\end{array}$ & $\begin{array}{l}0.1366 \\
(0.0983)\end{array}$ & $\begin{array}{l}0.0687 \\
(0.0973)\end{array}$ \\
\hline Share of commons & & $\begin{array}{l}-6.7183 * * * \\
(1.7901)\end{array}$ & $\begin{array}{l}-6.9889 * * * \\
(1.7014)\end{array}$ & $\begin{array}{l}-3.9017 * * \\
(1.5520)\end{array}$ \\
\hline Average of population, divided by 100 & & & $\begin{array}{l}-0.0155 \\
(0.0251)\end{array}$ & $\begin{array}{l}-0.1326^{* * * *} \\
(0.0355)\end{array}$ \\
\hline $\begin{array}{l}\text { Average of share of population aged } 65 \text { and } \\
\text { above }\end{array}$ & & & $\begin{array}{l}-11.3607 \\
(14.1712)\end{array}$ & $\begin{array}{l}-18.0765^{*} \\
(10.3538)\end{array}$ \\
\hline $\begin{array}{l}\text { Average of share of German speaking } \\
\text { population }\end{array}$ & & & $\begin{array}{l}-0.0402 * * * \\
(0.0115)\end{array}$ & $\begin{array}{l}-0.0197 * * \\
(0.0095)\end{array}$ \\
\hline Share of high school graduates & & & $\begin{array}{l}-0.2700^{*} \\
(0.1469)\end{array}$ & $\begin{array}{l}-0.2162 * \\
(0.1152)\end{array}$ \\
\hline Share of volunteers & & & $\begin{array}{l}1.2142 \\
(2.3480)\end{array}$ & $\begin{array}{l}2.8040 \\
(2.1700)\end{array}$ \\
\hline Average of number of hotel beds per capita & & & $\begin{array}{l}0.3222 \\
(0.4017)\end{array}$ & $\begin{array}{l}0.2407 \\
(0.3958)\end{array}$ \\
\hline Constant & $\begin{array}{l}73.7281 * * * \\
(0.7798)\end{array}$ & $\begin{array}{l}73.6802 * * * \\
(0.8042)\end{array}$ & $\begin{array}{l}85.8204 * * * \\
(5.0030)\end{array}$ & $\begin{array}{l}96.4898 * * * \\
(5.2820)\end{array}$ \\
\hline District-fixed effects included? & $x$ & $x$ & $x$ & $\checkmark$ \\
\hline Observations & 116 & 116 & 116 & 116 \\
\hline R squared & 0.1581 & 0.3693 & 0.4316 & 0.6907 \\
\hline
\end{tabular}

Robust standard errors in brackets. ${ }^{*}, * *, * * *$ indicate statistical significance at $10,5,1 \%$ level

\section{Results}

The number of entailed farms per 100 inhabitants in 1991 is positively correlated with voter turnout. The coefficient estimates of the number of entailed farms per 100 inhabitants for the full sample are positive and statistically significant at the 1 and $10 \%$ level (Table 2). The coefficient of entailed farms per 100 inhabitants in column (4) with all control variables included is 0.3 , indicating that voter turnout increases by around 0.74 percentage points (or $9 \%$ of a standard deviation) when the number of entailed farms per 100 inhabitants increases by one standard deviation.

Table 3 shows the results when we include dummy variables for the election types (municipal, national and European elections) and their interaction with the entailed farms per 100 inhabitants variable. The dummy variable for provincial elections is the reference category. The effects of entailed farms per 100 inhabitants on voter turnout differs in the types of election. 


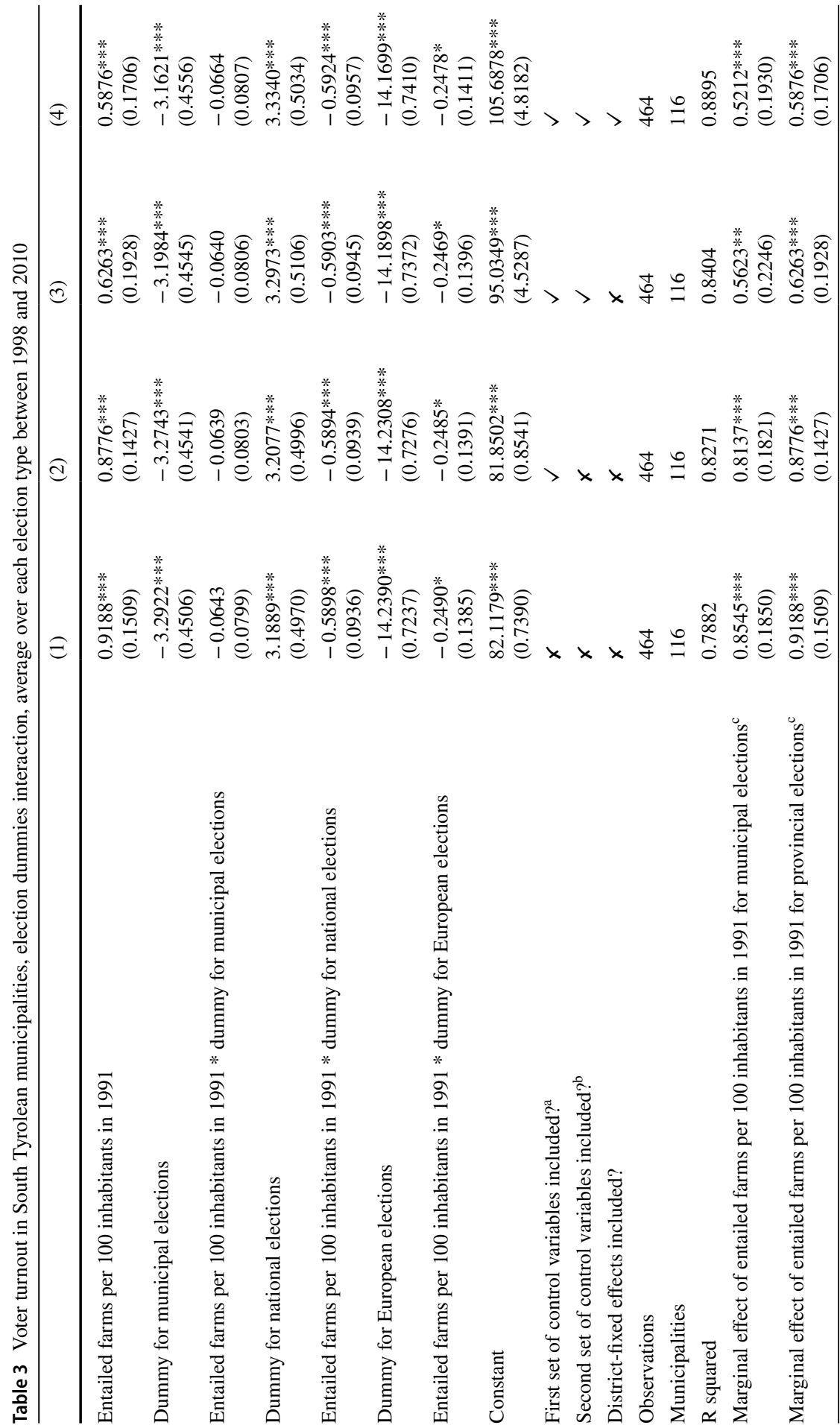




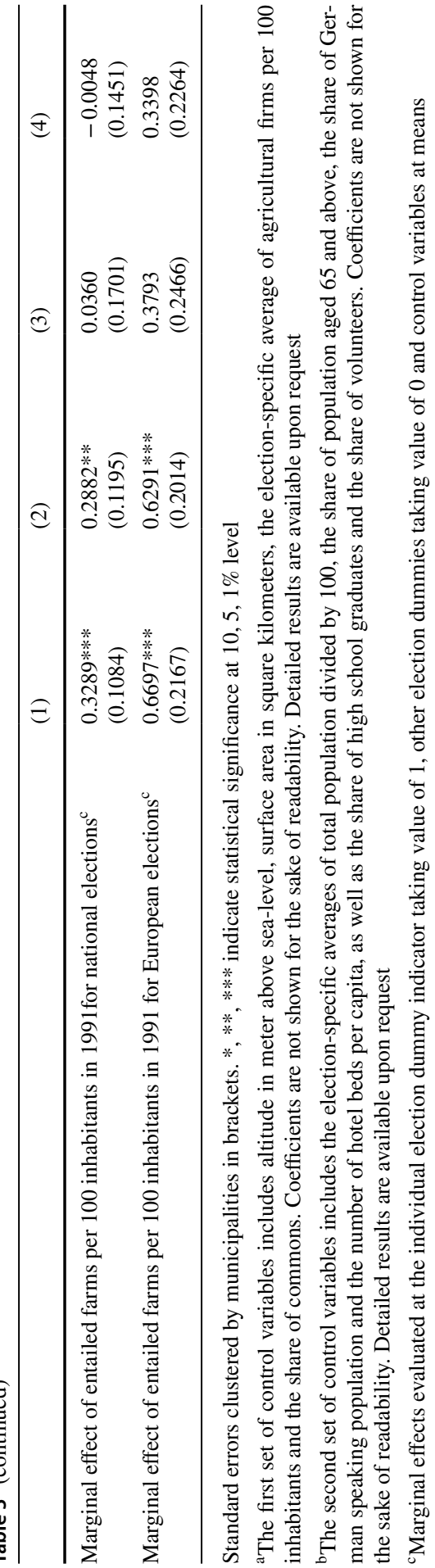


For the elections at the municipal and provincial level, the marginal effects of entailed farms per 100 inhabitants are larger than in the baseline model and are statistically significant at the $1 \%$ level when all control variables are included. If the number of entailed farms per 100 inhabitants increases by one standard deviation, voter turnout in municipal and provincial elections increases by 1.27 and 1.43 percentage points (or 25 and $35 \%$ of a standard deviation). The effect may be numerically larger for provincial elections because the provincial parliament has a larger legislative competence. The difference between the estimates for municipal and provincial elections does not turn out to be statistically significant, however, indicating that voters in municipalities with a high number of entailed farms per 100 inhabitants have a specific interest in voting for both local elections.

The marginal effects of entailed farms per 100 inhabitants on voter turnout for national and European elections are smaller than in local elections and lack statistical significance when the control variables are included (columns [3] and [4]). The stark difference regarding size and statistical significance between the marginal effects of the local government elections on one hand and of the European and central government elections on the other show that voters differentiate between election types. Our findings do not suggest that owners of entailed farms derive utility from voting per se. Instead, the results are compatible with either altruism or identity confirmation as drivers of the voting behavior of entailed farm owners. ${ }^{21}$

If we assume that all entailed farm owners vote but that they do not encourage others to vote, i.e. that the likelihood of voting for a citizen that does not own an entailed farm remains unchanged, we would expect a marginal effect on the entailed farms per 100 inhabitants variable of about 0.18 for municipal and of 0.15 for provincial elections. Our estimates are larger by a factor of 2.9 and 3.9 indicating that entailed farm owners encourage other voters in their municipality to go to the polls. $^{22}$

In Table 4 we consider the most recent elections over the period 2008-2010. The logarithm of income per capita is included as an additional control variable in these specifications. Overall, inferences regarding entailed farms per 100 inhabitants do not change. The coefficient estimates for entailed farms per 100 inhabitants remain positive and are statistically significant at the $1 \%$ level in column (1) and (2), and at the 5\% level in columns (3) and (4). The point estimate is slightly larger at 0.42 once all control variables are included. Voter turnout increases by about 1 percentage point (or $10 \%$ of a standard deviation) in the 2008-2010 sample when the number of entailed farms per 100 inhabitants increases by one standard deviation (column [4]).

Table 5 shows the estimations of the election-type interaction model using the sample period between 2008 and 2010. Again, inferences do not change. With all control variables included in column (4), the marginal effects of entailed farms remain positive and statistically significant for municipal and provincial elections.

\footnotetext{
${ }^{21}$ On regional identity formation see also Dehdari and Gehring (2019) and Gaebler (2020). On how group identity relates to voter turnout see Hillman et al. (2015).

22 We cannot rule out, of course, that the estimates constitute a case of ecological fallacy and we do not know which individuals turn up for the vote, because we do not have data on who exactly is voting. Aggregated macro variables tend to predict individual voting behavior quite well, however (see, for example, Alabrese et al. 2019; Potrafke and Roesel 2019).
} 
Table 4 Voter turnout in South Tyrolean municipalities, average over elections between 2008 and 2010

\begin{tabular}{|c|c|c|c|c|}
\hline & (1) & (2) & (3) & (4) \\
\hline Entailed farms per 100 inhabitants in 1991 & $\begin{array}{l}0.7728 * * * \\
(0.1480)\end{array}$ & $\begin{array}{l}0.6878 * * * \\
(0.1466)\end{array}$ & $\begin{array}{l}0.3955 * * \\
(0.1960)\end{array}$ & $\begin{array}{l}0.4233 * * \\
(0.1649)\end{array}$ \\
\hline Altitude above sea-level, in meters & & $\begin{array}{l}0.0011 \\
(0.0009)\end{array}$ & $\begin{array}{l}0.0005 \\
(0.0009)\end{array}$ & $\begin{array}{l}0.0017 * \\
(0.0009)\end{array}$ \\
\hline Surface area, in square kilometers & & $\begin{array}{l}-0.0078 \\
(0.0059)\end{array}$ & $\begin{array}{l}-0.0045 \\
(0.0053)\end{array}$ & $\begin{array}{l}0.0027 \\
(0.0038)\end{array}$ \\
\hline $\begin{array}{l}\text { Average of agricultural firms per } 100 \\
\text { inhabitants }\end{array}$ & & $\begin{array}{l}0.2837 * * * \\
(0.0803)\end{array}$ & $\begin{array}{l}0.3064 * * * \\
(0.1039)\end{array}$ & $\begin{array}{l}0.1497 \\
(0.0952)\end{array}$ \\
\hline Share of commons & & $\begin{array}{l}-5.9511 * * * \\
(1.8660)\end{array}$ & $\begin{array}{l}-4.8274 * * * \\
(1.7923)\end{array}$ & $\begin{array}{l}-2.9774 * * \\
(1.4614)\end{array}$ \\
\hline Average of population, divided by 100 & & & $\begin{array}{l}-0.0469^{*} \\
(0.0275)\end{array}$ & $\begin{array}{l}-0.1678 * * * \\
(0.0319)\end{array}$ \\
\hline $\begin{array}{l}\text { Average of share of population aged } 65 \text { and } \\
\text { above }\end{array}$ & & & $\begin{array}{l}-0.7716 \\
(17.0409)\end{array}$ & $\begin{array}{l}-5.5863 \\
(12.4823)\end{array}$ \\
\hline $\begin{array}{l}\text { Average of share of German speaking } \\
\text { population }\end{array}$ & & & $\begin{array}{l}-0.0369 * * * \\
(0.0124)\end{array}$ & $\begin{array}{l}-0.0208^{*} \\
(0.0122)\end{array}$ \\
\hline Share of high school graduates & & & $\begin{array}{l}-0.4341 * * * \\
(0.1391)\end{array}$ & $\begin{array}{l}-0.3393 * * * \\
(0.1070)\end{array}$ \\
\hline Share of volunteers & & & $\begin{array}{l}1.8091 \\
(2.4673)\end{array}$ & $\begin{array}{l}2.6999 \\
(2.1860)\end{array}$ \\
\hline Average of number of hotel beds per capita & & & $\begin{array}{l}-0.9844 * * \\
(0.4468)\end{array}$ & $\begin{array}{l}-0.8999 * * \\
(0.4142)\end{array}$ \\
\hline Income per capita, in logarithms & & & $\begin{array}{l}9.6996 * * * \\
(2.4908)\end{array}$ & $\begin{array}{l}7.0388 * * * \\
(2.6197)\end{array}$ \\
\hline Constant & $\begin{array}{l}74.9592 * * * \\
(0.7773)\end{array}$ & $\begin{array}{l}74.0976^{* * * *} \\
(0.8014)\end{array}$ & $\begin{array}{l}-5.2471 \\
(22.8809)\end{array}$ & $\begin{array}{l}31.4444 \\
(23.4678)\end{array}$ \\
\hline District-fixed effects included? & $x$ & $x$ & $x$ & $\checkmark$ \\
\hline Observations & 116 & 116 & 116 & 116 \\
\hline R squared & 0.2512 & 0.4131 & 0.5305 & 0.7275 \\
\hline
\end{tabular}

Robust standard errors in brackets. *, **, *** indicate statistical significance at $10,5,1 \%$ level

Voter turnout increases by 1.6 and 2.1 percentage points (31 and $48 \%$ of a standard deviation) if entailed farms per 100 inhabitants are increased by one standard deviation. The marginal effects for national or European elections do not turn out to be statistically significant. The size of the effect suggests, again, that entailed farm owners also encourage others to vote.

\section{Robustness checks}

We have included the average of millimeters of rain as recorded by the nearest weather station on the date of an election as an additional explanatory variable. Rain has been shown to influence voter turnout in other regions (see, for example, Gomez et al. 2007; Artes 2014; Lind 2019). As our entailed farms variable dates to 1991, 


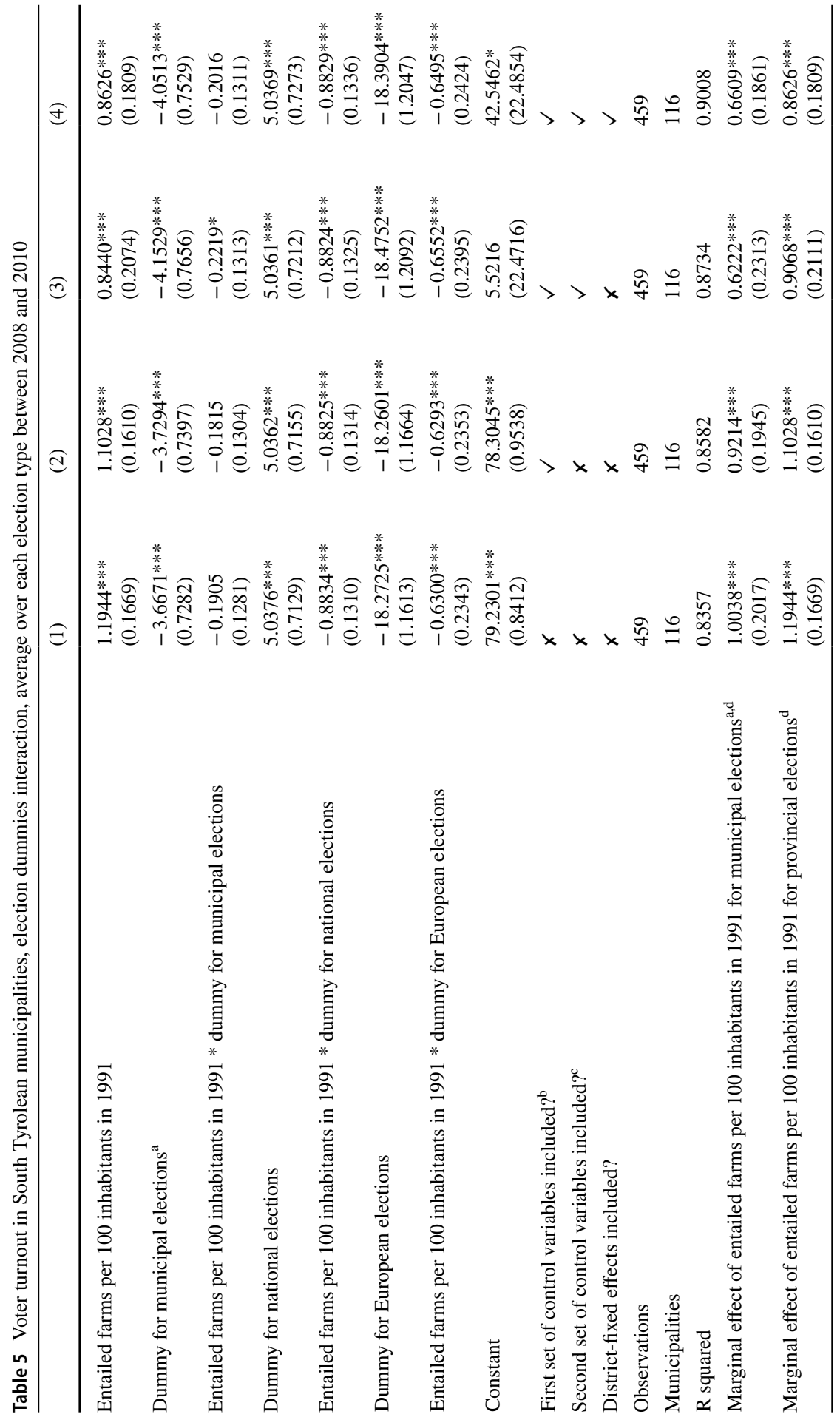




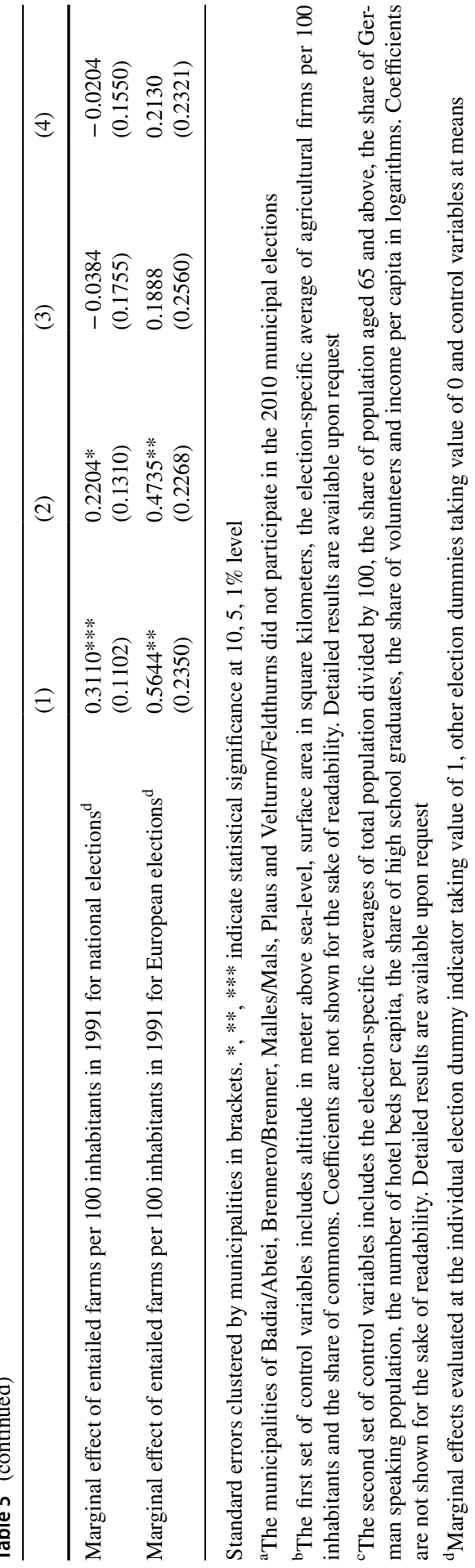


our rain variable covering the years 1998-2010 should not be correlated with the entailed farms variable. Indeed, the coefficients of entailed farms per 100 inhabitants in 1991 do not change substantially in size once the variable measuring rainfall is included. For municipal and provincial elections, the marginal effects of entailed farms per 100 inhabitants are still positive and statistically significant at the $1 \%$ level. The marginal effects of the entailed farm variable lack statistical significance for national and European elections.

We replaced the number of entailed farms per 100 inhabitants in each municipality in 1991 by the number of entailed farms per 100 inhabitants in each municipality in 1929. The coefficient estimates of the entailed farms per 100 inhabitants in 1929 are smaller in columns (1) and (2), but somewhat larger in columns (3) and (4). All coefficient estimates are statistically significant at the $1 \%$ level.

We employed alternative empirical techniques to investigate the robustness of our results, using voter turnout as our dependent variable. We used the panel structure of our model instead of an averaged cross-section to exploit variations over election dates in a sub-set of our control variables. We included a time trend variable in all panel model estimations and clustered standard errors by municipality. Inferences do not change. We also employed a spatial-autoregressive model with spatialautoregressive disturbances using a binary bordering municipality weighting matrix to address concerns of spatial autocorrelation. Again, inferences regarding entailed farms do not change. Finally, we used robust standard errors for our interaction models. The marginal effects of municipal and provincial elections remain positive and statistically significant.

We estimated the effect of entailed farms per 100 inhabitants in 1991 on the share of valid votes relative to total votes to make sure that the voter turnout results do not suffer from indirect voter attrition-meaning that voters turn out at the ballots, but do not cast their vote. Data on valid vote shares are available only for national and European elections. Using the average over election types between 1998 and 2010, the entailed farms per 100 inhabitants variable is positive and statistically significant at the 5\% level when all control variables are included. The results of the interaction model show that the effect is driven by national elections: if the number of entailed farms per 100 inhabitants increases by one standard deviation, the share of valid votes increases by $1.1 \%$ ( $20 \%$ of a standard deviation) once all control variables are included. The marginal effect does not turn out to be statistically significant for European elections. Inferences do not change if we use the sub-sample of elections between 2008 and 2010. Our results suggest that the presence of entailed farms relative to population decreases indirect voter attrition for national elections.

\section{Conclusions}

In South Tyrol, a selective inheritance rule mandating that only a single person can inherit a special type of agricultural property predicts voting behavior: voter turnout in South Tyrol is high in municipalities with many entailed farms per 100 inhabitants. Entailed farms, which constitute about two thirds of agricultural 
properties in the region and whose owners represent about $4.1 \%$ of the electorate, are regulated by a law of ancient origin by which the property is not divided among many heirs, but transmitted from the previous owner to just one descendant.

The positive effect of entailed farms on voter turnout is driven by local elections: if the number of entailed farms per 100 inhabitants increases by one standard deviation, voter turnout in municipal and provincial elections increases by 1.27 and 1.43 percentage points (or 25 and $35 \%$ of a standard deviation). The marginal effects of entailed farms per 100 inhabitants do not turn out to be statistically significant for national or European elections. Because the autonomy status in South Tyrol assigns important policy competencies to the municipal and provincial level, local elections may be perceived as more salient. Survey evidence from South Tyrol further suggests that owners of entailed farms feel that they are essential for the value system in the region and are called to play a prominent role in their community. The difference in voter turnout between local and non-local elections may then point to altruism à la Jankowski (2002) or a higher sense of civic duty through identity confirmation (Hamlin and Jennings 2011) as possible mechanisms to explain the voting behavior of entailed farm owners. Our results suggest that entailed farm owners themselves are more likely to cast their vote than other citizens. The size of the coefficients indicates that each entailed farm owner also encourages other citizens of their municipality to participate in local elections, too. We believe that the voting behavior of these agents is explained by social pressure which entailed farm owners exert.

Our study is embedded in a broader research agenda about the effect of inheritance traditions within families, and the possible link between intergenerational transmissions of property and voting behavior. While the legal institution of entailed farms is specific to South Tyrol, selective inheritance rules are part of local culture and institutions in many countries, and both inter- and intra-regional heterogeneity as well as micro-level voting data may be exploited to further investigate their specific effect on voting behavior.

Acknowledgements Open Access funding provided by Projekt DEAL. We would like to thank the editor Stefan Voigt and two anonymous referees, Werner Hintner, Natalie Obergruber, Felix Rösel, and the participants of the 2015 European Association of Law and Economics, the 2015 Italian Society of Public Economists, the 2015 Italian Economists Society, the 2016 European Public Choice Society, and the 2016 Silvaplana Workshop on Political Economy for helpful comments.

Open Access This article is licensed under a Creative Commons Attribution 4.0 International License, which permits use, sharing, adaptation, distribution and reproduction in any medium or format, as long as you give appropriate credit to the original author(s) and the source, provide a link to the Creative Commons licence, and indicate if changes were made. The images or other third party material in this article are included in the article's Creative Commons licence, unless indicated otherwise in a credit line to the material. If material is not included in the article's Creative Commons licence and your intended use is not permitted by statutory regulation or exceeds the permitted use, you will need to obtain permission directly from the copyright holder. To view a copy of this licence, visit http://creativecommons.org/licen ses/by/4.0/. 


\section{Appendix}

See Tables 6, 7, 8, 9, 10, 11, 12, 13, 14, 15, 16, 17, 18, 19, 20, 21, 22, 23 and 24.

Table 6 Voter turnout in South Tyrolean municipalities, average over all elections between 1998 and 2010 , robustness test: rain

\begin{tabular}{|c|c|c|c|c|}
\hline & (1) & (2) & (3) & (4) \\
\hline Entailed farms per 100 inhabitants in 1991 & $\begin{array}{l}0.5597 * * * \\
(0.1484)\end{array}$ & $\begin{array}{l}0.5326^{* * *} \\
(0.1515)\end{array}$ & $\begin{array}{l}0.3527^{*} \\
(0.2016)\end{array}$ & $\begin{array}{l}0.3023^{*} \\
(0.1670)\end{array}$ \\
\hline $\begin{array}{l}\text { Average of rain at election day, in millim- } \\
\text { eters }\end{array}$ & $\begin{array}{l}0.2365 \\
(0.2677)\end{array}$ & $\begin{array}{l}0.1449 \\
(0.2814)\end{array}$ & $\begin{array}{l}0.0656 \\
(0.3156)\end{array}$ & $\begin{array}{l}0.0603 \\
(0.3211)\end{array}$ \\
\hline Altitude above sea-level, in meters & & $\begin{array}{l}0.0008 \\
(0.0009)\end{array}$ & $\begin{array}{l}-0.0008 \\
(0.0010)\end{array}$ & $\begin{array}{l}-0.0000 \\
(0.0009)\end{array}$ \\
\hline Surface area, in square kilometers & & $\begin{array}{l}-0.0096 \\
(0.0060)\end{array}$ & $\begin{array}{l}-0.0085 \\
(0.0059)\end{array}$ & $\begin{array}{l}-0.0011 \\
(0.0045)\end{array}$ \\
\hline $\begin{array}{l}\text { Average of agricultural firms per } 100 \\
\text { inhabitants }\end{array}$ & & $\begin{array}{l}0.2033 * * \\
(0.0797)\end{array}$ & $\begin{array}{l}0.1348 \\
(0.1012)\end{array}$ & $\begin{array}{l}0.0708 \\
(0.0943)\end{array}$ \\
\hline Share of commons & & $\begin{array}{l}-6.7985^{* * *} \\
(1.7831)\end{array}$ & $\begin{array}{l}-7.0172 * * * \\
(1.7319)\end{array}$ & $\begin{array}{l}-3.9239 * * \\
(1.6004)\end{array}$ \\
\hline Average of population, divided by 100 & & & $\begin{array}{l}-0.0016 \\
(0.0025)\end{array}$ & $\begin{array}{l}-0.0133 * * * \\
(0.0036)\end{array}$ \\
\hline $\begin{array}{l}\text { Average of share of population aged } 65 \text { and } \\
\text { above }\end{array}$ & & & $\begin{array}{l}-11.2044 \\
(14.3443)\end{array}$ & $\begin{array}{l}-17.8257 * \\
(10.3839)\end{array}$ \\
\hline $\begin{array}{l}\text { Average of share of German speaking } \\
\text { population }\end{array}$ & & & $\begin{array}{l}-0.0400^{* * *} \\
(0.0114)\end{array}$ & $\begin{array}{l}-0.0197 * * \\
(0.0096)\end{array}$ \\
\hline Share of high school graduates & & & $\begin{array}{l}-0.2660^{*} \\
(0.1414)\end{array}$ & $\begin{array}{l}-0.2116^{*} \\
(0.1105)\end{array}$ \\
\hline Share of volunteers & & & $\begin{array}{l}1.2394 \\
(2.3493)\end{array}$ & $\begin{array}{l}2.8507 \\
(2.1674)\end{array}$ \\
\hline Average of number of hotel beds per capita & & & $\begin{array}{l}0.3098 \\
(0.3873)\end{array}$ & $\begin{array}{l}0.2308 \\
(0.3877)\end{array}$ \\
\hline Constant & $\begin{array}{l}73.0934 * * * \\
(1.0042)\end{array}$ & $\begin{array}{l}73.2680 * * * \\
(1.1301)\end{array}$ & $\begin{array}{l}85.4866 * * * \\
(4.6751)\end{array}$ & $\begin{array}{l}96.1869^{* * * *} \\
(4.9337)\end{array}$ \\
\hline District-fixed effects included? & $x$ & $x$ & $x$ & $\checkmark$ \\
\hline Observations & 116 & 116 & 116 & 116 \\
\hline $\mathrm{R}$ squared & 0.1635 & 0.3712 & 0.4320 & 0.6909 \\
\hline
\end{tabular}

Robust standard errors in brackets. *, **, *** indicate statistical significance at $10,5,1 \%$ level 


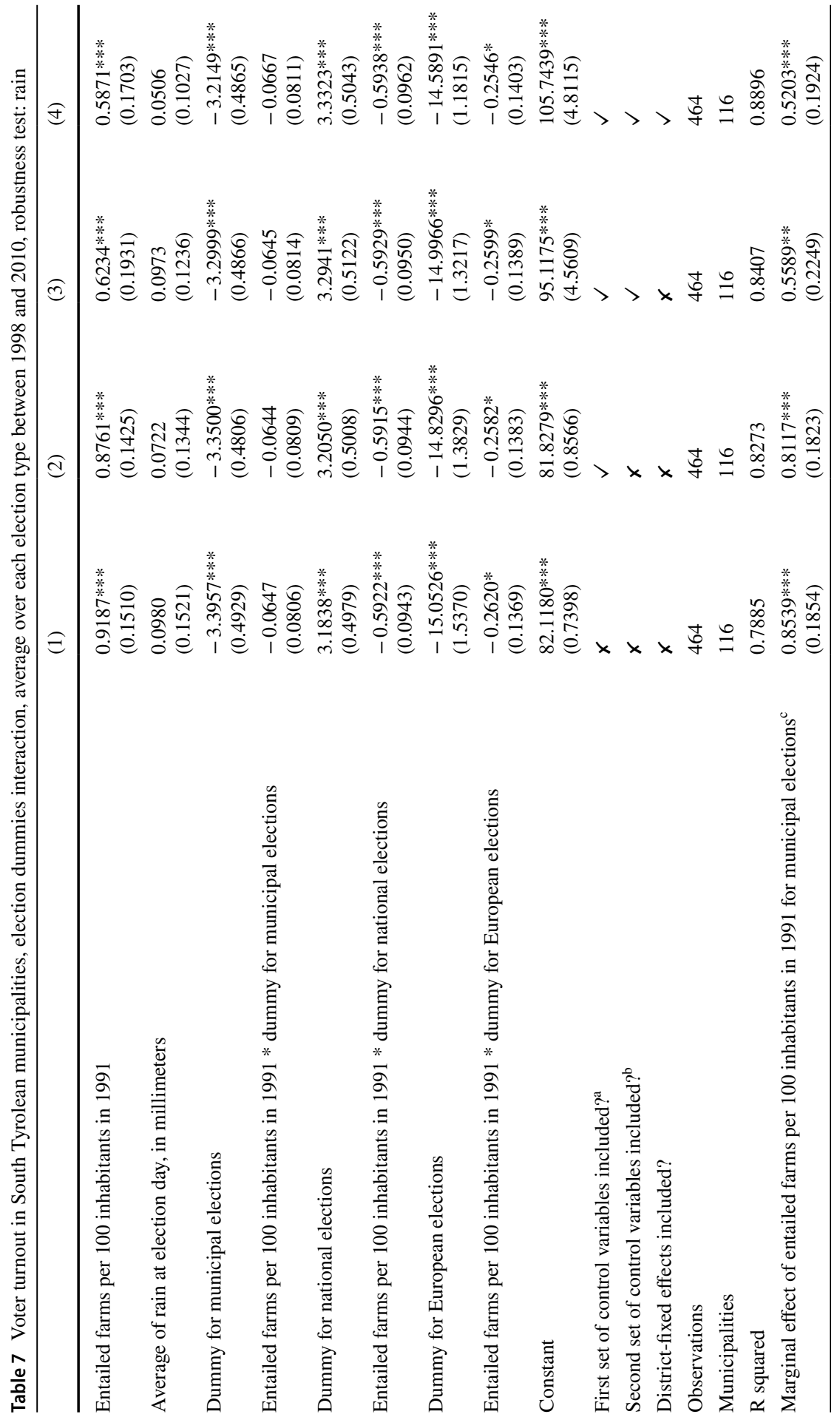




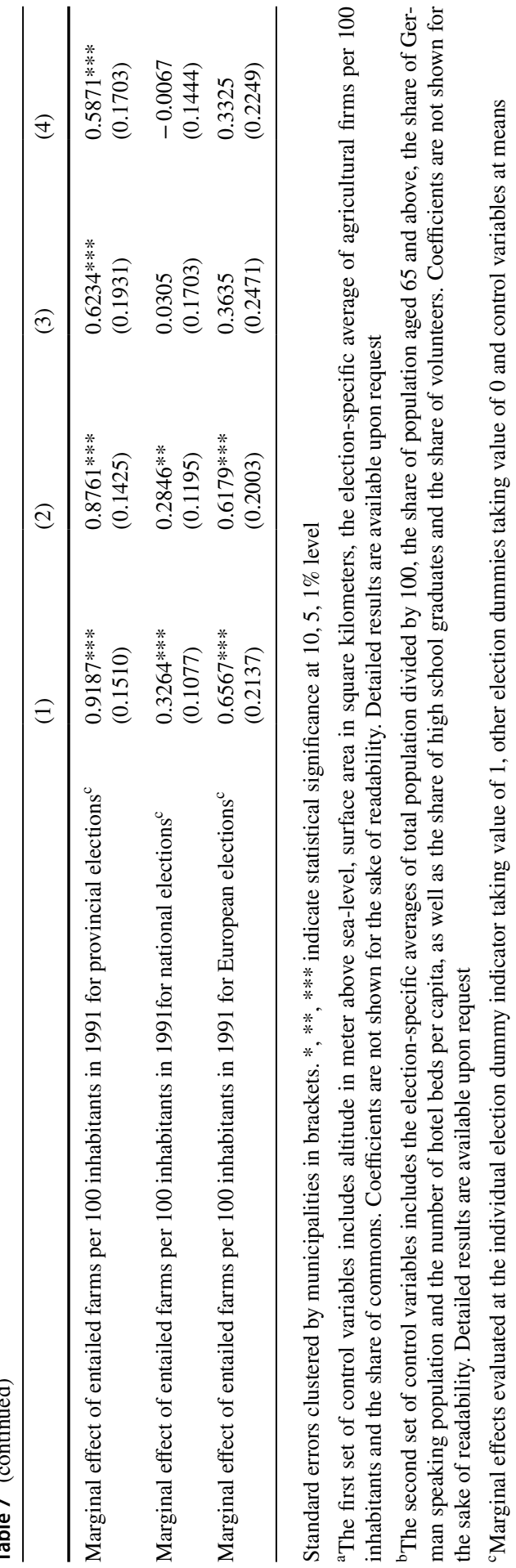


Table 8 Voter turnout in South Tyrolean municipalities, average over elections between 2008 and 2010, robustness test: rain

\begin{tabular}{|c|c|c|c|c|}
\hline & $(1)$ & (2) & (3) & (4) \\
\hline Per capita entailed farms, in 1991 & $\begin{array}{l}0.8437 * * * \\
(0.1287)\end{array}$ & $\begin{array}{l}0.7607 * * * \\
(0.1251)\end{array}$ & $\begin{array}{l}0.5459 * * * \\
(0.1661)\end{array}$ & $\begin{array}{l}0.4756^{* * * *} \\
(0.1599)\end{array}$ \\
\hline $\begin{array}{l}\text { Average of rain at election day, in millim- } \\
\text { eters }\end{array}$ & $\begin{array}{l}1.2216 * * * \\
(0.2660)\end{array}$ & $\begin{array}{l}1.0442 * * * \\
(0.2938)\end{array}$ & $\begin{array}{l}0.9372 * * * \\
(0.2669)\end{array}$ & $\begin{array}{l}0.3701 \\
(0.2815)\end{array}$ \\
\hline Altitude above sea-level, in meters & & $\begin{array}{l}0.0015^{*} \\
(0.0009)\end{array}$ & $\begin{array}{l}0.0006 \\
(0.0009)\end{array}$ & $\begin{array}{l}0.0021 * * \\
(0.0010)\end{array}$ \\
\hline Surface area, in square kilometers & & $\begin{array}{l}-0.0096^{*} \\
(0.0051)\end{array}$ & $\begin{array}{l}-0.0063 \\
(0.0051)\end{array}$ & $\begin{array}{l}0.0017 \\
(0.0040)\end{array}$ \\
\hline $\begin{array}{l}\text { Average of agricultural firms per } 100 \\
\text { inhabitants }\end{array}$ & & $\begin{array}{l}0.2042 * * * \\
(0.0696)\end{array}$ & $\begin{array}{l}0.2170 * * \\
(0.0985)\end{array}$ & $\begin{array}{l}0.1408 \\
(0.0972)\end{array}$ \\
\hline Share of commons & & $\begin{array}{l}-5.3497 * * * \\
(1.8145)\end{array}$ & $\begin{array}{l}-4.4337 * * \\
(1.7547)\end{array}$ & $\begin{array}{l}-3.1622 * * \\
(1.4681)\end{array}$ \\
\hline Average of population, divided by 100 & & & $\begin{array}{l}-0.0049 * * \\
(0.0024)\end{array}$ & $\begin{array}{l}-0.0170 * * * \\
(0.0033)\end{array}$ \\
\hline $\begin{array}{l}\text { Average of share of population aged } 65 \text { and } \\
\text { above }\end{array}$ & & & $\begin{array}{l}3.2975 \\
(15.7722)\end{array}$ & $\begin{array}{l}-2.9433 \\
(12.6421)\end{array}$ \\
\hline $\begin{array}{l}\text { Average of share of German speaking } \\
\text { population }\end{array}$ & & & $\begin{array}{l}-0.0339 * * * \\
(0.0114)\end{array}$ & $\begin{array}{l}-0.0240^{*} \\
(0.0124)\end{array}$ \\
\hline Share of high school graduates & & & $\begin{array}{l}-0.3507 * * * \\
(0.1188)\end{array}$ & $\begin{array}{l}-0.3252 * * * \\
(0.1008)\end{array}$ \\
\hline Share of volunteers & & & $\begin{array}{l}2.8425 \\
(2.3523)\end{array}$ & $\begin{array}{l}2.5538 \\
(2.1755)\end{array}$ \\
\hline Average of number of hotel beds per capita & & & $\begin{array}{l}-0.7443^{*} \\
(0.4309)\end{array}$ & $\begin{array}{l}-0.9938 * * \\
(0.4328)\end{array}$ \\
\hline Income per capita, in logarithms & & & $\begin{array}{l}8.6213 * * * \\
(2.3178)\end{array}$ & $\begin{array}{l}7.8344 * * * \\
(2.6863)\end{array}$ \\
\hline Constant & $\begin{array}{l}72.2430 * * * \\
(0.8390)\end{array}$ & $\begin{array}{l}71.9578 * * * \\
(0.9753)\end{array}$ & $\begin{array}{l}0.0849 \\
(21.9102)\end{array}$ & $\begin{array}{l}22.3380 \\
(24.4973)\end{array}$ \\
\hline District-fixed effects included? & $x$ & $x$ & $x$ & $\checkmark$ \\
\hline Observations & 116 & 116 & 116 & 116 \\
\hline R squared & 0.3768 & 0.4973 & 0.5938 & 0.7333 \\
\hline
\end{tabular}

Robust standard errors in brackets. *, **, *** indicate statistical significance at $10,5,1 \%$ level 


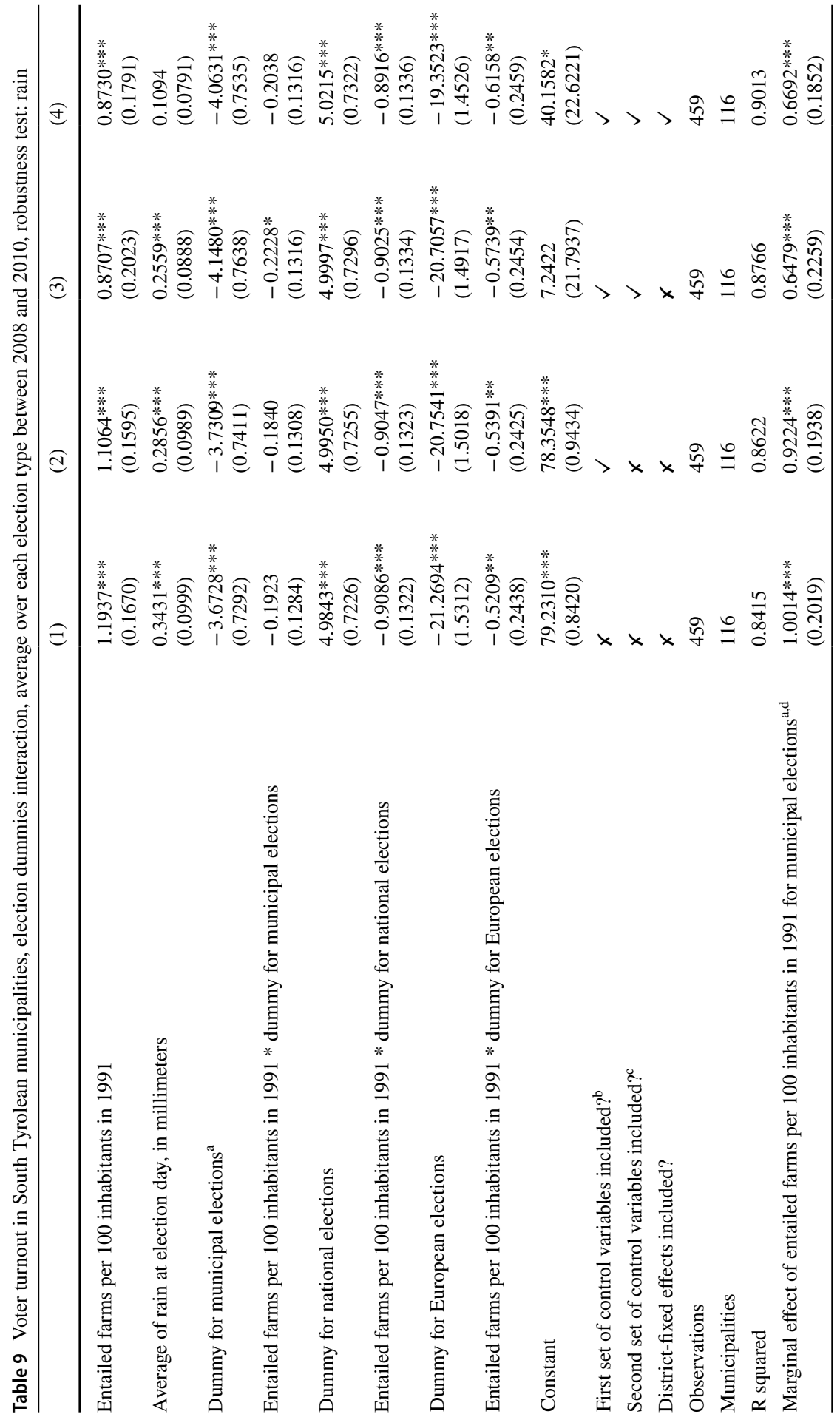




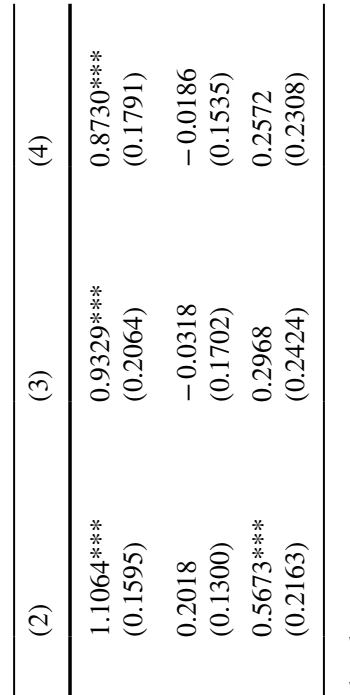

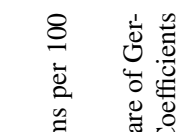

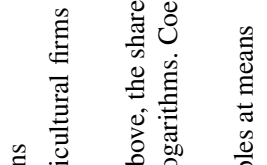

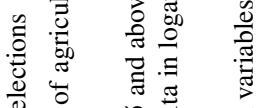

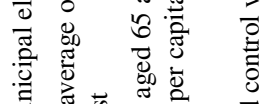

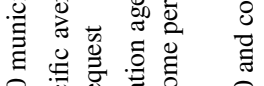

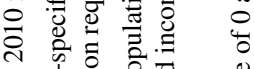

‡

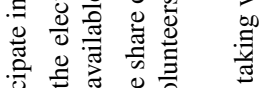

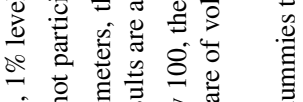

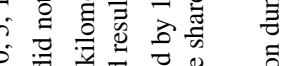

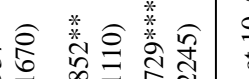

$\approx$ a $\overrightarrow{0}$ च छ

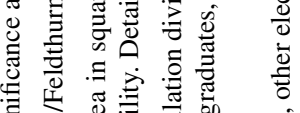

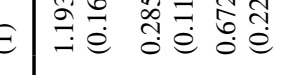

政

:

:

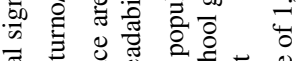

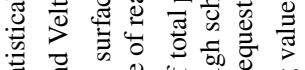

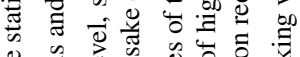

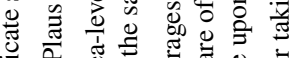

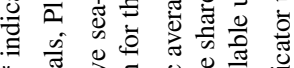

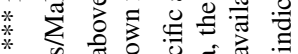

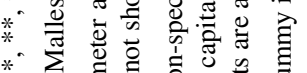

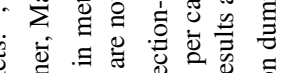

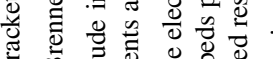

兑 总

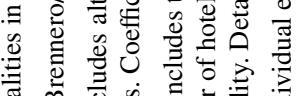

急

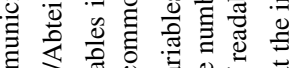

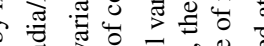

ठี

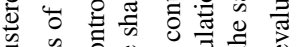

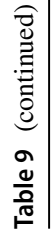

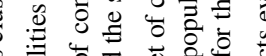

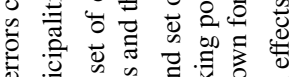

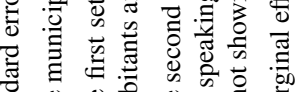

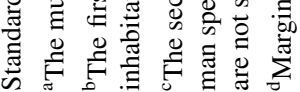


Table 10 Voter turnout in South Tyrolean municipalities, average over all elections between 1998 and 2010, robustness test: entailed farms per 100 inhabitants in 1929

\begin{tabular}{|c|c|c|c|c|}
\hline & (1) & (2) & (3) & $(4)$ \\
\hline Entailed farms per 100 inhabitants in 1929 & $\begin{array}{l}0.3103 * * * \\
(0.0907)\end{array}$ & $\begin{array}{l}0.4471 * * * \\
(0.1013)\end{array}$ & $\begin{array}{l}0.5462 * * * \\
(0.1501)\end{array}$ & $\begin{array}{l}0.5408 * * * \\
(0.1035)\end{array}$ \\
\hline Altitude above sea-level, in meters & & $\begin{array}{l}-0.0004 \\
(0.0009)\end{array}$ & $\begin{array}{l}-0.0010 \\
(0.0009)\end{array}$ & $\begin{array}{l}-0.0021^{* *} \\
(0.0011)\end{array}$ \\
\hline Surface area, in square kilometers & & $\begin{array}{l}-0.0030 \\
(0.0061)\end{array}$ & $\begin{array}{l}-0.0001 \\
(0.0061)\end{array}$ & $\begin{array}{l}0.0023 \\
(0.0043)\end{array}$ \\
\hline $\begin{array}{l}\text { Average of agricultural firms per } 100 \text { inhabit- } \\
\text { ants }\end{array}$ & & $\begin{array}{l}0.2605 * * * \\
(0.0767)\end{array}$ & $\begin{array}{l}0.2201 * * \\
(0.0962)\end{array}$ & $\begin{array}{l}0.0157 \\
(0.0942)\end{array}$ \\
\hline Share of commons & & $\begin{array}{l}-6.3917 * * * \\
(1.2114)\end{array}$ & $\begin{array}{l}-7.0817 * * * \\
(1.3775)\end{array}$ & $\begin{array}{l}-3.7210^{* * *} \\
(1.5621)\end{array}$ \\
\hline Average of population, divided by 100 & & & $\begin{array}{l}-0.0029^{*} \\
(0.0017)\end{array}$ & $\begin{array}{l}-0.0132^{* * *} \\
(0.0050)\end{array}$ \\
\hline $\begin{array}{l}\text { Average of share of population aged } 65 \text { and } \\
\text { above }\end{array}$ & & & $\begin{array}{l}11.9579 \\
(14.7161)\end{array}$ & $\begin{array}{l}2.1692 \\
(10.0222)\end{array}$ \\
\hline $\begin{array}{l}\text { Average of share of German speaking } \\
\text { population }\end{array}$ & & & $\begin{array}{l}-0.0362^{* * * *} \\
(0.0134)\end{array}$ & $\begin{array}{l}-0.0106 \\
(0.0092)\end{array}$ \\
\hline Share of high school graduates & & & $\begin{array}{l}-0.0641 \\
(0.1260)\end{array}$ & $\begin{array}{l}-0.1020 \\
(0.1008)\end{array}$ \\
\hline Share of volunteers & & & $\begin{array}{l}2.7013 \\
(2.5264)\end{array}$ & $\begin{array}{l}5.6687 * * \\
(2.2138)\end{array}$ \\
\hline Average of number of hotel beds per capita & & & $\begin{array}{l}-0.8515 \\
(0.5116)\end{array}$ & $\begin{array}{l}-0.2362 \\
(0.4114)\end{array}$ \\
\hline Constant & $\begin{array}{l}74.0679 * * * \\
(0.7329)\end{array}$ & $\begin{array}{l}73.2064 * * * \\
(0.8706)\end{array}$ & $\begin{array}{l}75.4305 * * * \\
(5.2223)\end{array}$ & $\begin{array}{l}87.1361 * * * \\
(5.9491)\end{array}$ \\
\hline District-fixed effects included? & $x$ & $x$ & $x$ & $\checkmark$ \\
\hline Observations & 89 & 89 & 89 & 89 \\
\hline $\mathrm{R}$ squared & 0.1289 & 0.4177 & 0.4788 & 0.7277 \\
\hline
\end{tabular}

Robust standard errors in brackets. ${ }^{*}, * *, * * *$ indicate statistical significance at $10,5,1 \%$ level 


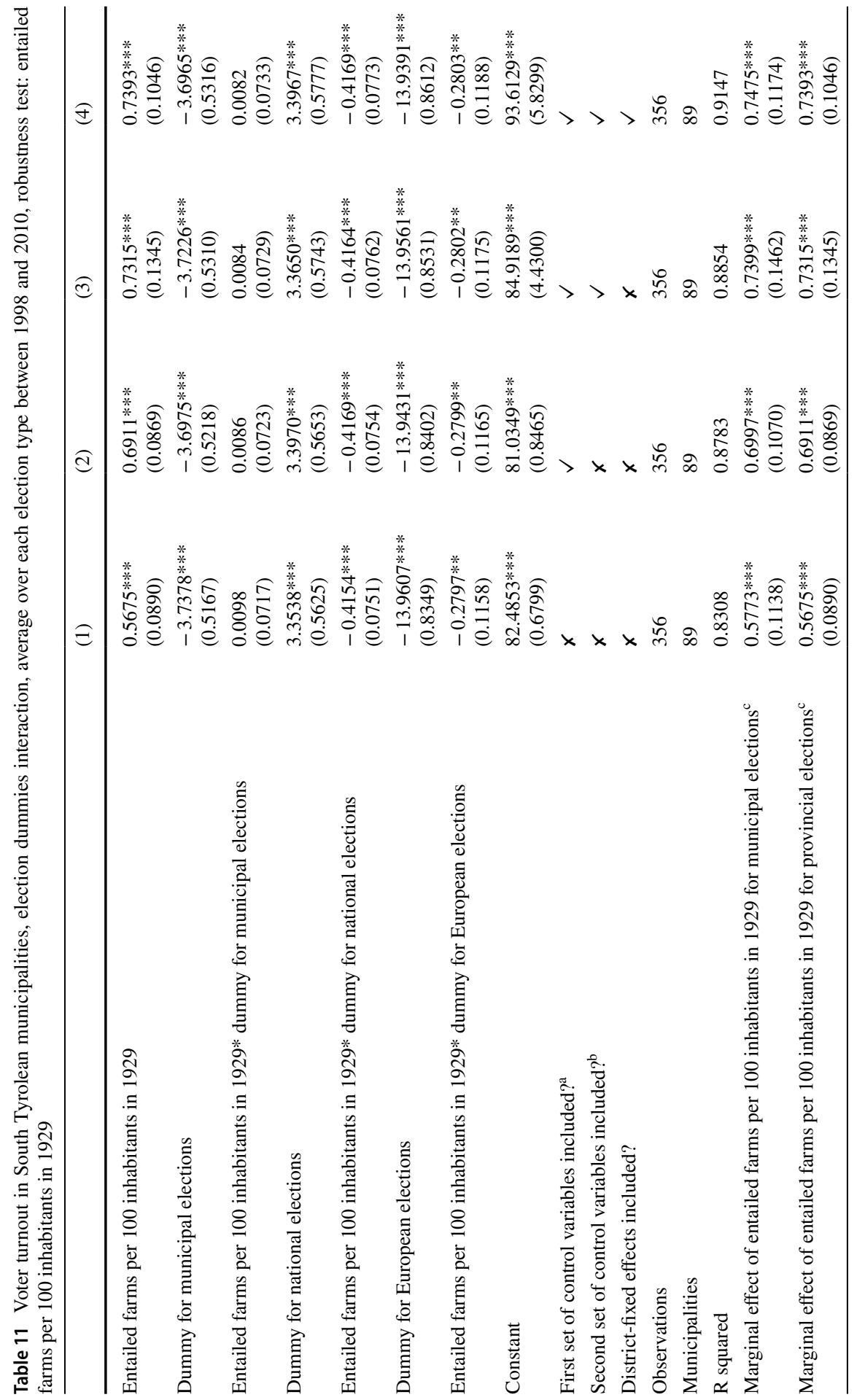




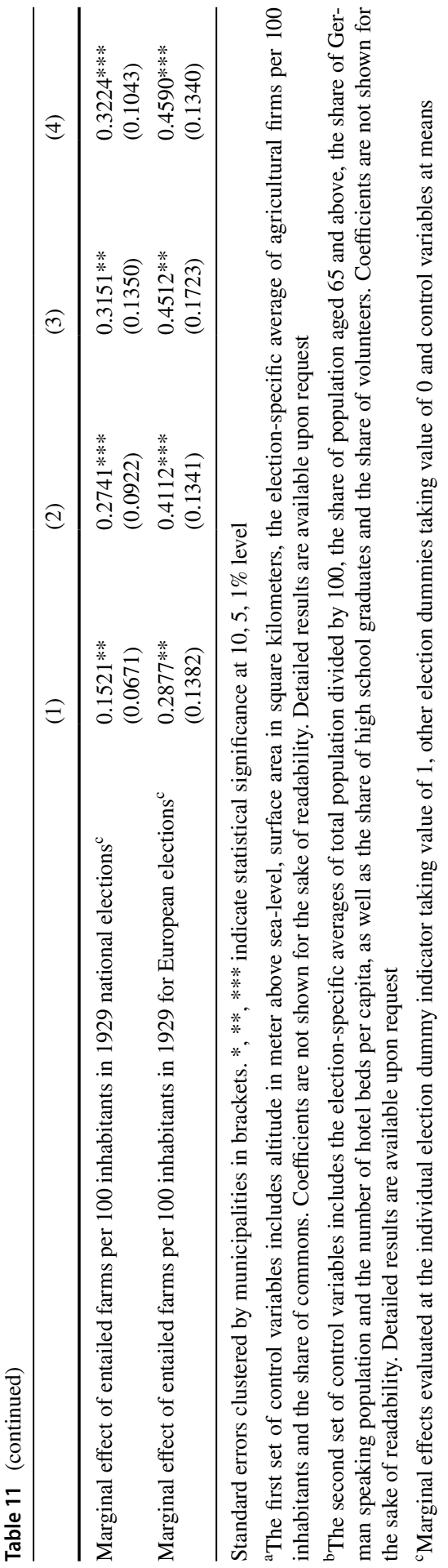


Table 12 Voter turnout in South Tyrolean municipalities, average over elections between 2008 and 2010, robustness test: entailed farms per 100 inhabitants in 1929

\begin{tabular}{|c|c|c|c|c|}
\hline & (1) & (2) & (3) & (4) \\
\hline Per capita entailed farms, in 1929 & $\begin{array}{l}0.4100 * * * \\
(0.0894)\end{array}$ & $\begin{array}{l}0.5002 * * * \\
(0.0921)\end{array}$ & $\begin{array}{l}0.5704 * * * \\
(0.1368)\end{array}$ & $\begin{array}{l}0.5880 * * * \\
(0.1240)\end{array}$ \\
\hline Altitude above sea-level, in meters & & $\begin{array}{l}0.0001 \\
(0.0009)\end{array}$ & $\begin{array}{l}-0.0001 \\
(0.0008)\end{array}$ & $\begin{array}{l}-0.0001 \\
(0.0011)\end{array}$ \\
\hline Surface area, in square kilometers & & $\begin{array}{l}-0.0003 \\
(0.0058)\end{array}$ & $\begin{array}{l}0.0052 \\
(0.0053)\end{array}$ & $\begin{array}{l}0.0068 \\
(0.0041)\end{array}$ \\
\hline $\begin{array}{l}\text { Average of agricultural firms per } 100 \\
\text { inhabitants }\end{array}$ & & $\begin{array}{l}0.3884 * * * \\
(0.0703)\end{array}$ & $\begin{array}{l}0.3752 * * * \\
(0.0901)\end{array}$ & $\begin{array}{l}0.1339 \\
(0.0899)\end{array}$ \\
\hline Share of commons & & $\begin{array}{l}-5.8808 * * * \\
(1.3233)\end{array}$ & $\begin{array}{l}-6.2817 * * * \\
(1.4415)\end{array}$ & $\begin{array}{l}-3.9159 * * * \\
(1.4678)\end{array}$ \\
\hline Average of population, divided by 100 & & & $\begin{array}{l}-0.0055^{* * * *} \\
(0.0015)\end{array}$ & $\begin{array}{l}-0.0099 * \\
(0.0053)\end{array}$ \\
\hline $\begin{array}{l}\text { Average of share of population aged } 65 \text { and } \\
\text { above }\end{array}$ & & & $\begin{array}{l}22.3808 \\
(15.4595)\end{array}$ & $\begin{array}{l}13.1653 \\
(12.0946)\end{array}$ \\
\hline $\begin{array}{l}\text { Average of share of German speaking } \\
\text { population }\end{array}$ & & & $\begin{array}{l}-0.0353 * * \\
(0.0146)\end{array}$ & $\begin{array}{l}-0.0129 \\
(0.0127)\end{array}$ \\
\hline Share of high school graduates & & & $\begin{array}{l}-0.2135^{*} \\
(0.1177)\end{array}$ & $\begin{array}{l}-0.2271 * * \\
(0.0946)\end{array}$ \\
\hline Share of volunteers & & & $\begin{array}{l}5.0395 * * \\
(2.4918)\end{array}$ & $\begin{array}{l}7.5774 * * * \\
(2.5105)\end{array}$ \\
\hline Average of number of hotel beds per capita & & & $\begin{array}{l}-1.8336^{* * * *} \\
(0.5457)\end{array}$ & $\begin{array}{l}-1.2159 * * * \\
(0.4131)\end{array}$ \\
\hline Income per capita, in logarithms & & & $\begin{array}{l}7.0867 * * * \\
(2.5121)\end{array}$ & $\begin{array}{l}5.3369 * * \\
(2.5337)\end{array}$ \\
\hline Constant & $\begin{array}{l}75.4422 * * * \\
(0.7115)\end{array}$ & $\begin{array}{l}73.5293^{* * * *} \\
(0.8378)\end{array}$ & $\begin{array}{l}8.7559 \\
(22.3983)\end{array}$ & $\begin{array}{l}31.0690 \\
(23.3391)\end{array}$ \\
\hline District-fixed effects included? & $x$ & $x$ & $x$ & $\checkmark$ \\
\hline Observations & 89 & 89 & 89 & 89 \\
\hline $\mathrm{R}$ squared & 0.1976 & 0.4648 & 0.5794 & 0.7418 \\
\hline
\end{tabular}

Robust standard errors in brackets. ${ }^{*}, * *, * * *$ indicate statistical significance at $10,5,1 \%$ level 


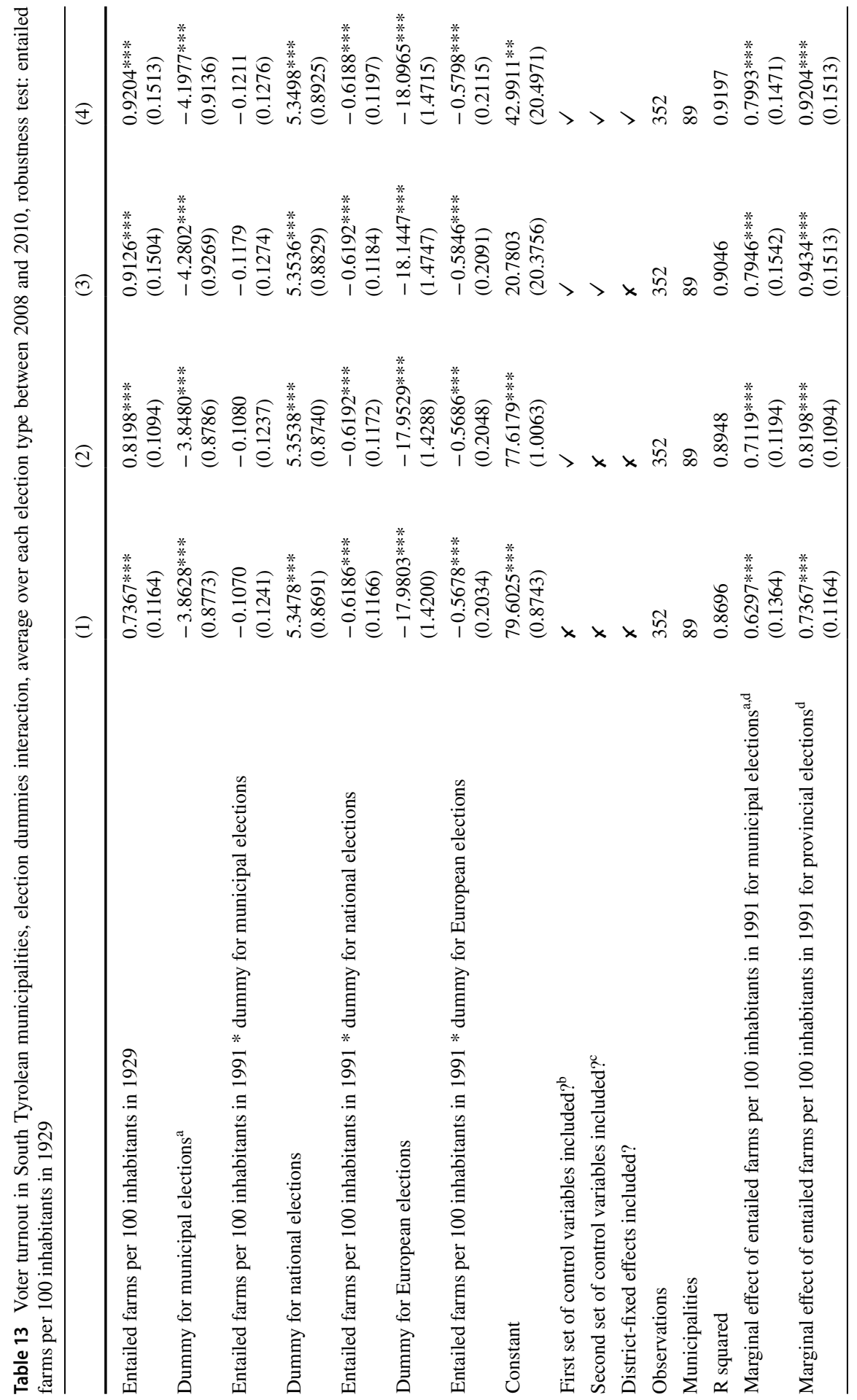




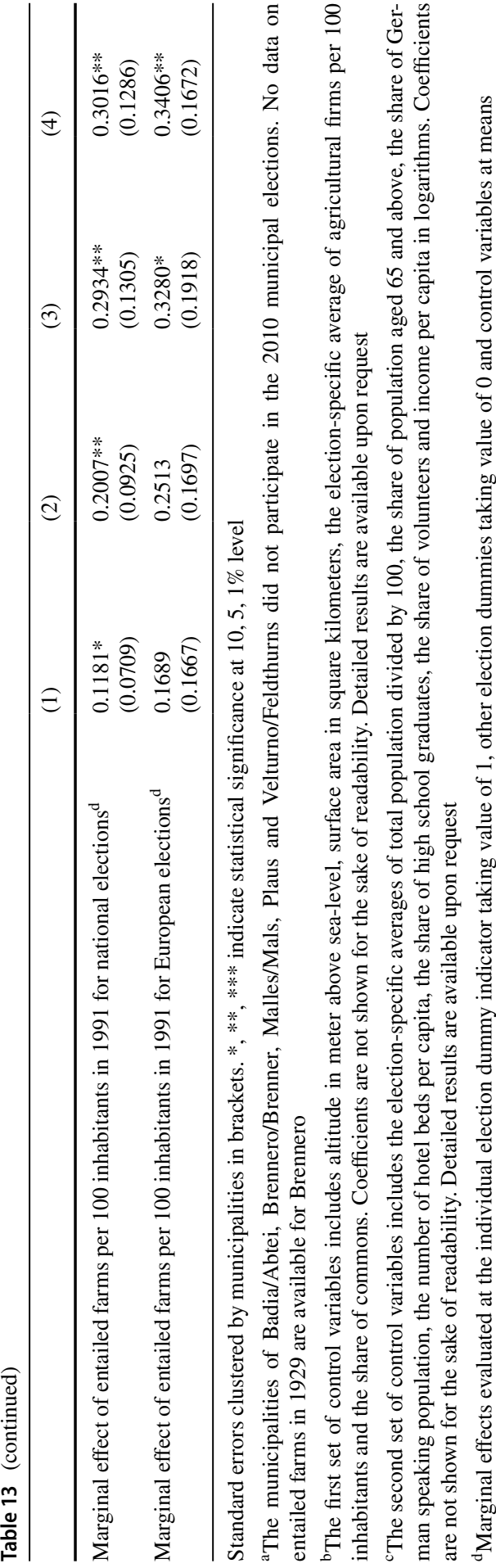


Table 14 Robustness test: share of valid votes in South Tyrolean municipalities, average over all national and European elections between 1998 and 2010

\begin{tabular}{|c|c|c|c|c|}
\hline & (1) & (2) & (3) & (4) \\
\hline Entailed farms per 100 inhabitants in 1991 & $\begin{array}{l}-0.1513 \\
(0.1048)\end{array}$ & $\begin{array}{l}0.1078 \\
(0.0997)\end{array}$ & $\begin{array}{l}0.2054 \\
(0.1401)\end{array}$ & $\begin{array}{l}0.3080 * * \\
(0.1359)\end{array}$ \\
\hline Altitude above sea-level, in meters & & $\begin{array}{l}-0.0028 * * * \\
(0.0007)\end{array}$ & $\begin{array}{l}-0.0018^{* *} \\
(0.0008)\end{array}$ & $\begin{array}{l}-0.0009 \\
(0.0007)\end{array}$ \\
\hline Surface area, in square kilometers & & $\begin{array}{l}-0.0079 * \\
(0.0043)\end{array}$ & $\begin{array}{l}-0.0099 * * \\
(0.0046)\end{array}$ & $\begin{array}{l}-0.0094 * * \\
(0.0046)\end{array}$ \\
\hline $\begin{array}{l}\text { Average of agricultural firms per } 100 \text { inhabit- } \\
\text { ants }\end{array}$ & & $\begin{array}{l}-0.2394 * * * \\
(0.0632)\end{array}$ & $\begin{array}{l}-0.0848 \\
(0.0776)\end{array}$ & $\begin{array}{l}-0.1613^{* *} \\
(0.0783)\end{array}$ \\
\hline Share of commons & & $\begin{array}{l}-1.1394 \\
(1.1647)\end{array}$ & $\begin{array}{l}-0.6772 \\
(1.1766)\end{array}$ & $\begin{array}{l}0.4990 \\
(1.2289)\end{array}$ \\
\hline Average of population, divided by 100 & & & $\begin{array}{l}0.0051 * * * \\
(0.0016)\end{array}$ & $\begin{array}{l}0.0121 * * \\
(0.0053)\end{array}$ \\
\hline $\begin{array}{l}\text { Average of share of population aged } 65 \text { and } \\
\text { above }\end{array}$ & & & $\begin{array}{l}-10.4327 \\
(10.9456)\end{array}$ & $\begin{array}{l}-17.5698 * \\
(9.8711)\end{array}$ \\
\hline $\begin{array}{l}\text { Average of share of German speaking popula- } \\
\text { tion }\end{array}$ & & & $\begin{array}{l}0.0195 \\
(0.0127)\end{array}$ & $\begin{array}{l}0.0307 * * * \\
(0.0097)\end{array}$ \\
\hline Share of high school graduates & & & $\begin{array}{l}0.1707 * * \\
(0.0841)\end{array}$ & $\begin{array}{l}0.1685^{* *} \\
(0.0830)\end{array}$ \\
\hline Share of volunteers & & & $\begin{array}{l}-2.1558 \\
(2.1699)\end{array}$ & $\begin{array}{l}0.1081 \\
(2.1672)\end{array}$ \\
\hline Average of number of hotel beds per capita & & & $\begin{array}{l}0.3329 \\
(0.4369)\end{array}$ & $\begin{array}{l}0.6604 \\
(0.4517)\end{array}$ \\
\hline Constant & $\begin{array}{l}90.6484 * * * \\
(0.4824)\end{array}$ & $\begin{array}{l}94.2205^{* * * *} \\
(0.6077)\end{array}$ & $\begin{array}{l}89.0464 * * * \\
(3.3635)\end{array}$ & $\begin{array}{l}81.3397 * * * \\
(5.2223)\end{array}$ \\
\hline District-fixed effects included? & $x$ & $x$ & $x$ & $\checkmark$ \\
\hline Observations & 116 & 116 & 116 & 116 \\
\hline $\mathrm{R}$ squared & 0.0186 & 0.2949 & 0.3656 & 0.5850 \\
\hline
\end{tabular}

Robust standard errors in brackets. ${ }^{*}, * *, * * *$ indicate statistical significance at $10,5,1 \%$ level Data are available only for national and European elections 


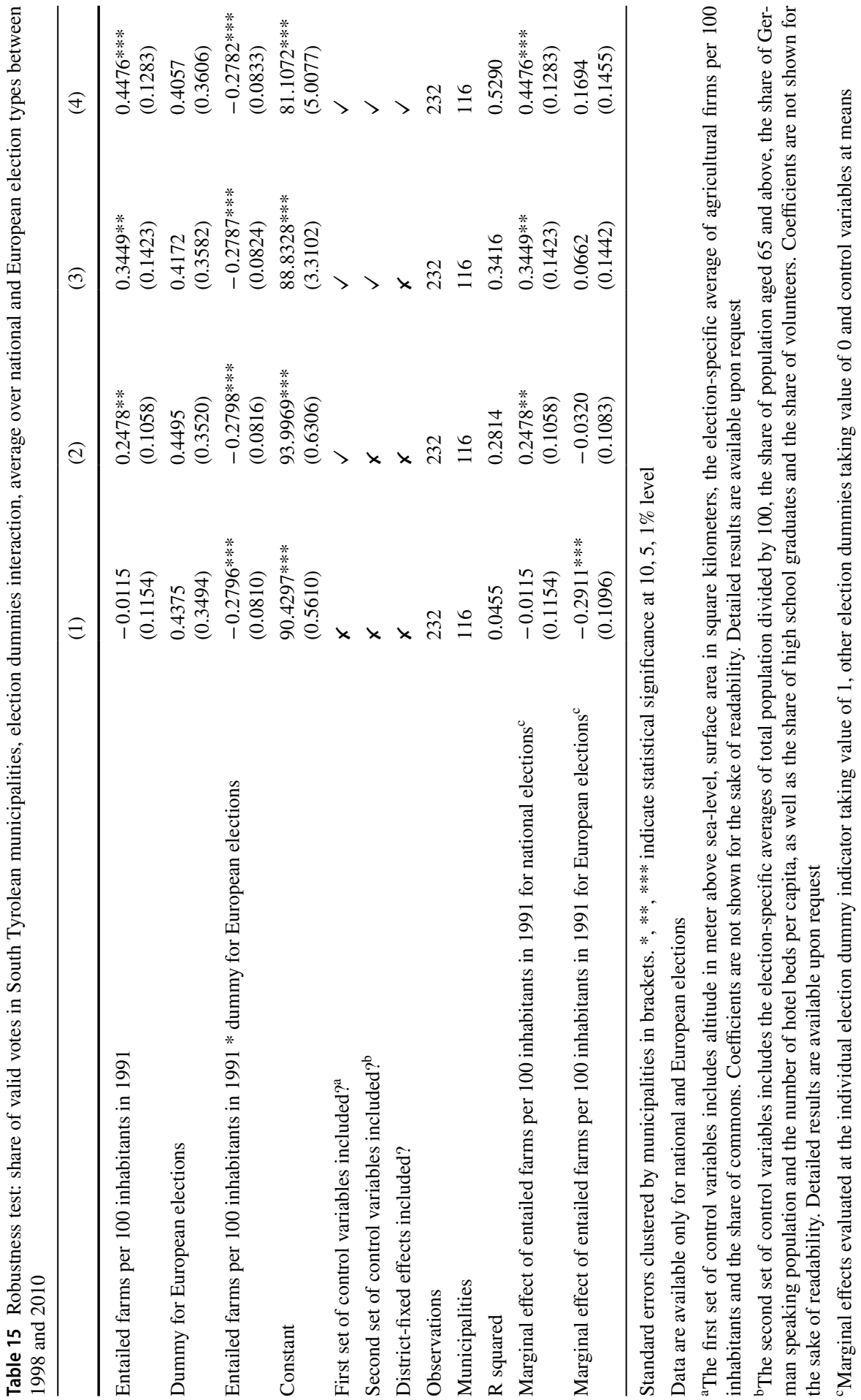


Table 16 Robustness test: share of valid votes in South Tyrolean municipalities, average over national and European elections between 2008 and 2010

\begin{tabular}{|c|c|c|c|c|}
\hline & (1) & (2) & (3) & (4) \\
\hline Entailed farms per 100 inhabitants in 1991 & $\begin{array}{l}-0.2781 * * * \\
(0.0939)\end{array}$ & $\begin{array}{l}-0.0485 \\
(0.1051)\end{array}$ & $\begin{array}{l}0.0787 \\
(0.1582)\end{array}$ & $\begin{array}{l}0.2767^{*} \\
(0.1612)\end{array}$ \\
\hline Altitude above sea-level, in meters & & $\begin{array}{l}-0.0024 * * * \\
(0.0007)\end{array}$ & $\begin{array}{l}-0.0010 \\
(0.0008)\end{array}$ & $\begin{array}{l}-0.0002 \\
(0.0009)\end{array}$ \\
\hline Surface area, in square kilometers & & $\begin{array}{l}-0.0079 * \\
(0.0044)\end{array}$ & $\begin{array}{l}-0.0088^{*} \\
(0.0045)\end{array}$ & $\begin{array}{l}-0.0098 * * \\
(0.0047)\end{array}$ \\
\hline $\begin{array}{l}\text { Average of agricultural firms per } 100 \text { inhabit- } \\
\text { ants }\end{array}$ & & $\begin{array}{l}-0.2190 * * * \\
(0.0741)\end{array}$ & $\begin{array}{l}0.0255 \\
(0.0894)\end{array}$ & $\begin{array}{l}-0.1420 \\
(0.0920)\end{array}$ \\
\hline Share of commons & & $\begin{array}{l}-0.2153 \\
(1.2698)\end{array}$ & $\begin{array}{l}1.1648 \\
(1.4038)\end{array}$ & $\begin{array}{l}0.7895 \\
(1.4190)\end{array}$ \\
\hline Average of population, divided by 100 & & & $\begin{array}{l}0.0035^{*} \\
(0.0018)\end{array}$ & $\begin{array}{l}0.0079 \\
(0.0059)\end{array}$ \\
\hline $\begin{array}{l}\text { Average of share of population aged } 65 \text { and } \\
\text { above }\end{array}$ & & & $\begin{array}{l}-16.6292 \\
(13.4319)\end{array}$ & $\begin{array}{l}-22.2104^{*} \\
(12.6811)\end{array}$ \\
\hline $\begin{array}{l}\text { Average of share of German speaking popula- } \\
\text { tion }\end{array}$ & & & $\begin{array}{l}0.0117 \\
(0.0114)\end{array}$ & $\begin{array}{l}0.0153 \\
(0.0109)\end{array}$ \\
\hline Share of high school graduates & & & $\begin{array}{l}0.1953^{*} \\
(0.1006)\end{array}$ & $\begin{array}{l}0.1738^{*} \\
(0.1006)\end{array}$ \\
\hline Share of volunteers & & & $\begin{array}{l}-2.4466 \\
(2.3841)\end{array}$ & $\begin{array}{l}-0.7436 \\
(2.4692)\end{array}$ \\
\hline Average of number of hotel beds per capita & & & $\begin{array}{l}-0.0744 \\
(0.5634)\end{array}$ & $\begin{array}{l}0.2541 \\
(0.6509)\end{array}$ \\
\hline Income per capita, in logarithms & & & $\begin{array}{l}2.6648 \\
(2.7553)\end{array}$ & $\begin{array}{l}1.8464 \\
(3.1500)\end{array}$ \\
\hline Constant & $\begin{array}{l}92.0792 * * * \\
(0.4353)\end{array}$ & $\begin{array}{l}95.1057^{* * * *} \\
(0.6831)\end{array}$ & $\begin{array}{l}65.1728 * * \\
(25.6426)\end{array}$ & $\begin{array}{l}69.6418 * * \\
(28.8194)\end{array}$ \\
\hline District-fixed effects included? & $x$ & $x$ & $x$ & $\checkmark$ \\
\hline Observations & 116 & 116 & 116 & 116 \\
\hline R squared & 0.0626 & 0.2666 & 0.3667 & 0.4813 \\
\hline
\end{tabular}

Robust standard errors in brackets. *, **, *** indicate statistical significance at $10,5,1 \%$ level Data are available only for national and European elections 


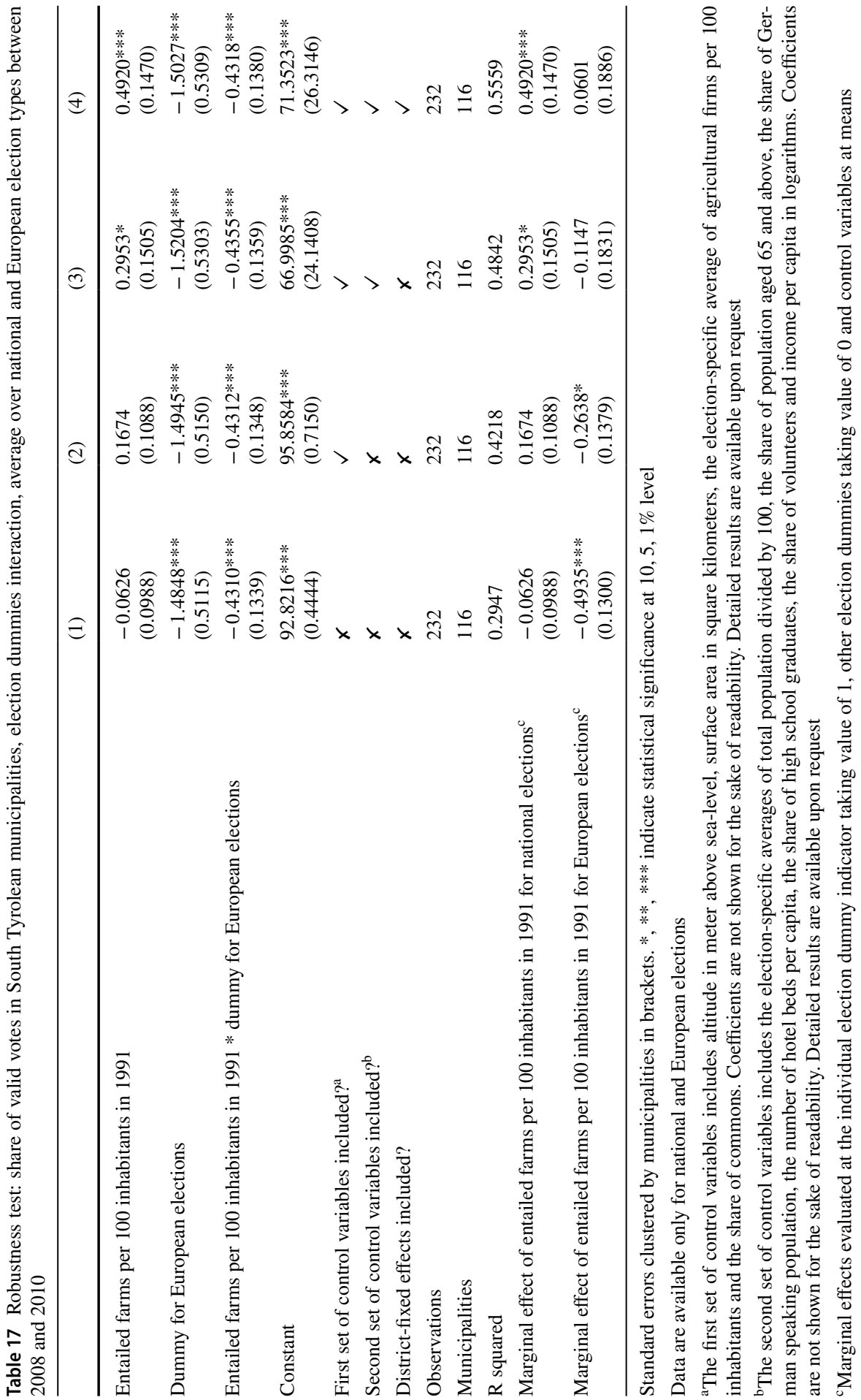


Table 18 Voter turnout in South Tyrolean municipalities, average over all elections between 1998 and 2010, robustness test: panel

\begin{tabular}{|c|c|c|c|c|}
\hline & $(1)$ & (2) & (3) & (4) \\
\hline $\begin{array}{l}\text { Entailed farms per } 100 \text { inhabitants in } \\
1991\end{array}$ & $\begin{array}{l}0.6897 * * * \\
(0.1525)\end{array}$ & $\begin{array}{l}0.6466 * * * \\
(0.1452)\end{array}$ & $\begin{array}{l}0.3903 * * \\
(0.1940)\end{array}$ & $\begin{array}{l}0.3530 * * \\
(0.1652)\end{array}$ \\
\hline Altitude above sea-level, in meters & & $\begin{array}{l}0.0006 \\
(0.0008)\end{array}$ & $\begin{array}{l}-0.0008 \\
(0.0009)\end{array}$ & $\begin{array}{l}-0.0001 \\
(0.0008)\end{array}$ \\
\hline Surface area, in square kilometers & & $\begin{array}{l}-0.0069 \\
(0.0057)\end{array}$ & $\begin{array}{l}-0.0056 \\
(0.0053)\end{array}$ & $\begin{array}{l}0.0015 \\
(0.0035)\end{array}$ \\
\hline $\begin{array}{l}\text { Average of agricultural firms per } 100 \\
\text { inhabitants }\end{array}$ & & $\begin{array}{l}0.2295 * * * \\
(0.0734)\end{array}$ & $\begin{array}{l}0.1697 * \\
(0.0874)\end{array}$ & $\begin{array}{l}0.1076 \\
(0.0847)\end{array}$ \\
\hline Share of commons & & $\begin{array}{l}-6.3339 * * * \\
(1.7701)\end{array}$ & $\begin{array}{l}-6.4889 * * * \\
(1.6353)\end{array}$ & $\begin{array}{l}-3.6174 * * \\
(1.4381)\end{array}$ \\
\hline Average of population, divided by 100 & & & $\begin{array}{l}-0.0018 \\
(0.0023)\end{array}$ & $\begin{array}{l}-0.0134 * * * \\
(0.0028)\end{array}$ \\
\hline $\begin{array}{l}\text { Average of share of population aged } 65 \\
\text { and above }\end{array}$ & & & $\begin{array}{l}-22.5951 * \\
(12.5609)\end{array}$ & $\begin{array}{l}-27.9097 * * * \\
(9.2988)\end{array}$ \\
\hline $\begin{array}{l}\text { Average of share of German speaking } \\
\text { population }\end{array}$ & & & $\begin{array}{l}-0.0328 * * * \\
(0.0105)\end{array}$ & $\begin{array}{l}-0.0141 \\
(0.0094)\end{array}$ \\
\hline Share of high school graduates & & & $\begin{array}{l}-0.2690 * * \\
(0.1282)\end{array}$ & $\begin{array}{l}-0.2174 * * \\
(0.0959)\end{array}$ \\
\hline Share of volunteers & & & $\begin{array}{l}0.9096 \\
(2.1879)\end{array}$ & $\begin{array}{l}2.3404 \\
(1.8840)\end{array}$ \\
\hline $\begin{array}{l}\text { Average of number of hotel beds per } \\
\text { capita }\end{array}$ & & & $\begin{array}{l}0.4217 \\
(0.3784)\end{array}$ & $\begin{array}{l}0.3400 \\
(0.3473)\end{array}$ \\
\hline Constant & $\begin{array}{l}100.4781 * * * \\
(1.0574)\end{array}$ & $\begin{array}{l}99.7422 * * * \\
(1.0854)\end{array}$ & $\begin{array}{l}111.0214 * * * \\
(4.2081)\end{array}$ & $\begin{array}{l}120.9738 * * * \\
(4.3749)\end{array}$ \\
\hline Time trend included? & $\checkmark$ & $\checkmark$ & $\checkmark$ & $\checkmark$ \\
\hline District-fixed effects included? & $x$ & $x$ & $x$ & $\checkmark$ \\
\hline Observations & 1383 & 1383 & 1383 & 1383 \\
\hline Municipalities & 116 & 116 & 116 & 116 \\
\hline R squared & 0.0954 & 0.1286 & 0.1402 & 0.1813 \\
\hline
\end{tabular}

Robust standard errors in brackets. *, **, *** indicate statistical significance at $10,5,1 \%$ level 


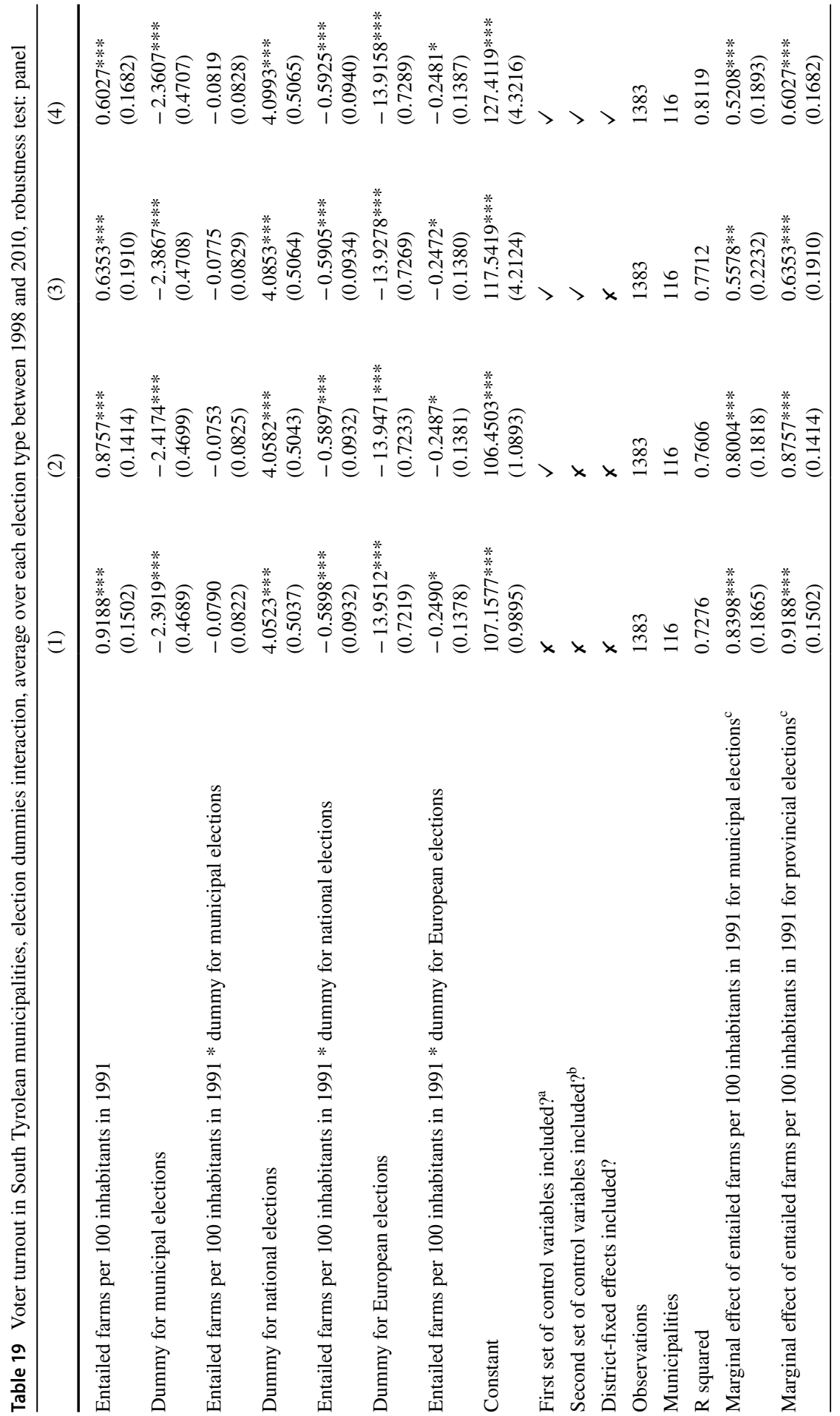




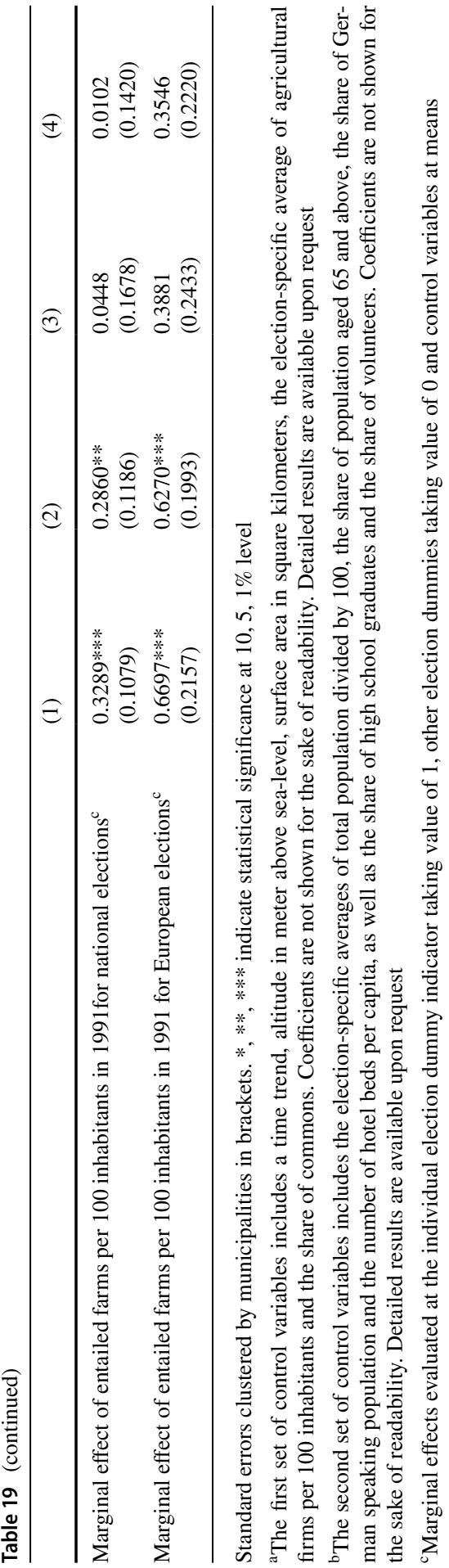


Table 20 Voter turnout in South Tyrolean municipalities, average over elections between 2008 and 2010, robustness test: panel

\begin{tabular}{|c|c|c|c|c|}
\hline & (1) & (2) & (3) & (4) \\
\hline $\begin{array}{l}\text { Entailed farms per } 100 \text { inhabitants in } \\
1991\end{array}$ & $\begin{array}{l}0.7723 * * * \\
(0.1483)\end{array}$ & $\begin{array}{l}0.6850 * * * \\
(0.1446)\end{array}$ & $\begin{array}{l}0.4131 * * \\
(0.1925)\end{array}$ & $\begin{array}{l}0.4315 * * * \\
(0.1590)\end{array}$ \\
\hline Altitude above sea-level, in meters & & $\begin{array}{l}0.0012 \\
(0.0009)\end{array}$ & $\begin{array}{l}0.0000 \\
(0.0008)\end{array}$ & $\begin{array}{l}0.0007 \\
(0.0009)\end{array}$ \\
\hline Surface area, in square kilometers & & $\begin{array}{l}-0.0079 \\
(0.0061)\end{array}$ & $\begin{array}{l}-0.0053 \\
(0.0055)\end{array}$ & $\begin{array}{l}0.0018 \\
(0.0041)\end{array}$ \\
\hline $\begin{array}{l}\text { Average of agricultural firms per } 100 \\
\text { inhabitants }\end{array}$ & & $\begin{array}{l}0.2971 * * * \\
(0.0789)\end{array}$ & $\begin{array}{l}0.2420 * * \\
(0.1074)\end{array}$ & $\begin{array}{l}0.0732 \\
(0.0937)\end{array}$ \\
\hline Share of commons & & $\begin{array}{l}-6.1557 * * * \\
(1.8232)\end{array}$ & $\begin{array}{l}-5.5806 * * * \\
(1.7856)\end{array}$ & $\begin{array}{l}-3.3318 * * \\
(1.4312)\end{array}$ \\
\hline Average of population, divided by 100 & & & $\begin{array}{l}-0.0038 \\
(0.0023)\end{array}$ & $\begin{array}{l}-0.0131 * * * \\
(0.0031)\end{array}$ \\
\hline $\begin{array}{l}\text { Average of share of population aged } 65 \\
\text { and above }\end{array}$ & & & $\begin{array}{l}-7.9682 \\
(16.3002)\end{array}$ & $\begin{array}{l}-14.8166 \\
(12.4093)\end{array}$ \\
\hline $\begin{array}{l}\text { Average of share of German speaking } \\
\text { population }\end{array}$ & & & $\begin{array}{l}-0.0358 * * * \\
(0.0119)\end{array}$ & $\begin{array}{l}-0.0153 \\
(0.0116)\end{array}$ \\
\hline Share of high school graduates & & & $\begin{array}{l}-0.3742 * * * \\
(0.1380)\end{array}$ & $\begin{array}{l}-0.2679 * * \\
(0.1062)\end{array}$ \\
\hline Share of volunteers & & & $\begin{array}{l}2.7005 \\
(2.3845)\end{array}$ & $\begin{array}{l}4.4145 * * \\
(2.0802)\end{array}$ \\
\hline $\begin{array}{l}\text { Average of number of hotel beds per } \\
\text { capita }\end{array}$ & & & $\begin{array}{l}-0.4799 \\
(0.4312)\end{array}$ & $\begin{array}{l}-0.1333 \\
(0.4082)\end{array}$ \\
\hline Income per capita, in logarithms & & & $\begin{array}{l}5.6934 * * \\
(2.6208)\end{array}$ & $\begin{array}{l}1.6429 \\
(2.8400)\end{array}$ \\
\hline Constant & $\begin{array}{l}278.3748 * * * \\
(8.6450)\end{array}$ & $\begin{array}{l}278.0804^{* * * *} \\
(9.1001)\end{array}$ & $\begin{array}{l}246.5468 * * * \\
(21.0722)\end{array}$ & $\begin{array}{l}286.0109 * * * \\
(22.3263)\end{array}$ \\
\hline Time trend included? & $\checkmark$ & $\checkmark$ & $\checkmark$ & $\checkmark$ \\
\hline District-fixed effects included? & $x$ & $x$ & $x$ & $\checkmark$ \\
\hline Observations & 459 & 459 & 459 & 459 \\
\hline Municipalities & 116 & 116 & 116 & 116 \\
\hline $\mathrm{R}$ squared & 0.1280 & 0.1523 & 0.1635 & 0.1935 \\
\hline
\end{tabular}

Robust standard errors in brackets. ${ }^{*}, * *, * * *$ indicate statistical significance at $10,5,1 \%$ level 
Table 21 Voter turnout in South Tyrolean municipalities, average over elections between 1998 and 2010, robustness test: spatial-autoregressive model with spatial-autoregressive disturbances

\begin{tabular}{|c|c|c|c|c|}
\hline & (1) & (2) & (3) & (4) \\
\hline Entailed farms per 100 inhabitants in 1991 & $\begin{array}{l}0.6536 * * * \\
(0.1063)\end{array}$ & $\begin{array}{l}0.3776 * * * \\
(0.1194)\end{array}$ & $\begin{array}{l}0.1547 \\
(0.1357)\end{array}$ & $\begin{array}{l}0.2421 * \\
(0.1331)\end{array}$ \\
\hline Altitude above sea-level, in meters & & $\begin{array}{l}0.0013 \\
(0.0008)\end{array}$ & $\begin{array}{l}0.0003 \\
(0.0009)\end{array}$ & $\begin{array}{l}0.0004 \\
(0.0009)\end{array}$ \\
\hline Surface area, in square kilometers & & $\begin{array}{l}-0.0014 \\
(0.0036)\end{array}$ & $\begin{array}{l}0.0008 \\
(0.0035)\end{array}$ & $\begin{array}{l}0.0001 \\
(0.0036)\end{array}$ \\
\hline $\begin{array}{l}\text { Average of agricultural firms per } 100 \\
\text { inhabitants }\end{array}$ & & $\begin{array}{l}0.3171 * * * \\
(0.0857)\end{array}$ & $\begin{array}{l}0.1975 * * \\
(0.0946)\end{array}$ & $\begin{array}{l}0.0922 \\
(0.0900)\end{array}$ \\
\hline Share of commons & & $\begin{array}{l}-3.9739 * * * \\
(1.2178)\end{array}$ & $\begin{array}{l}-3.6599 * * * \\
(1.1955)\end{array}$ & $\begin{array}{l}-4.0032 * * * \\
(1.1538)\end{array}$ \\
\hline Average of population, divided by 100 & & & $\begin{array}{l}-0.0023 \\
(0.0023)\end{array}$ & $\begin{array}{l}-0.0147 * * * \\
(0.0052)\end{array}$ \\
\hline $\begin{array}{l}\text { Average of share of population aged } 65 \text { and } \\
\text { above }\end{array}$ & & & $\begin{array}{l}-20.7654 * * \\
(9.8883)\end{array}$ & $\begin{array}{l}-17.2586^{*} \\
(9.3836)\end{array}$ \\
\hline $\begin{array}{l}\text { Average of share of German speaking } \\
\text { population }\end{array}$ & & & $\begin{array}{l}-0.0110 \\
(0.0136)\end{array}$ & $\begin{array}{l}-0.0162 \\
(0.0107)\end{array}$ \\
\hline Share of high school graduates & & & $\begin{array}{l}-0.1923^{* * *} \\
(0.0853)\end{array}$ & $\begin{array}{l}-0.1967 * * \\
(0.0806)\end{array}$ \\
\hline Share of volunteers & & & $\begin{array}{l}3.0932 * \\
(1.7592)\end{array}$ & $\begin{array}{l}2.3419 \\
(1.8513)\end{array}$ \\
\hline Average of number of hotel beds per capita & & & $\begin{array}{l}0.2261 \\
(0.4287)\end{array}$ & $\begin{array}{l}0.1084 \\
(0.4221)\end{array}$ \\
\hline Constant & $\begin{array}{l}71.3779 * * * \\
(2.3730)\end{array}$ & $\begin{array}{l}70.5521 * * * \\
(2.2634)\end{array}$ & $\begin{array}{l}79.9498 * * * \\
(3.9951)\end{array}$ & $\begin{array}{l}94.8794 * * * \\
(6.2822)\end{array}$ \\
\hline District-fixed effects included? & $x$ & $x$ & $x$ & $\checkmark$ \\
\hline Observations & 116 & 116 & 116 & 116 \\
\hline Lambda constant & $\begin{array}{l}0.0310 \\
(0.0317)\end{array}$ & $\begin{array}{l}0.0225 \\
(0.0289)\end{array}$ & $\begin{array}{l}0.0167 \\
(0.0273)\end{array}$ & $\begin{array}{l}0.0285 \\
(0.0255)\end{array}$ \\
\hline Rho constant & $\begin{array}{l}0.6669 * * * \\
(0.0755)\end{array}$ & $\begin{array}{l}0.6878 * * * \\
(0.0765)\end{array}$ & $\begin{array}{l}0.7246 * * * \\
(0.0701)\end{array}$ & $\begin{array}{l}0.2400 \\
(0.1761)\end{array}$ \\
\hline Sigma squared constant & $\begin{array}{l}5.6493 * * * \\
(0.7637)\end{array}$ & $\begin{array}{l}4.4816^{* * * *} \\
(0.6088)\end{array}$ & $\begin{array}{l}3.9142 * * * \\
(0.5329)\end{array}$ & $\begin{array}{l}3.5499 * * * \\
(0.4705)\end{array}$ \\
\hline
\end{tabular}

Robust standard errors in brackets. *, **, *** indicate statistical significance at $10,5,1 \%$ level 
Table 22 Voter turnout in South Tyrolean municipalities, average over elections between 2008 and 2010, robustness test: spatial-autoregressive model with spatial-autoregressive disturbances

\begin{tabular}{|c|c|c|c|c|}
\hline & (1) & $(2)$ & (3) & (4) \\
\hline Entailed farms per 100 inhabitants in 1991 & $\begin{array}{l}0.8790 * * * \\
(0.1155)\end{array}$ & $\begin{array}{l}0.5520 * * * \\
(0.1267)\end{array}$ & $\begin{array}{l}0.2776^{*} \\
(0.1421)\end{array}$ & $\begin{array}{l}0.3972 * * * \\
(0.1338)\end{array}$ \\
\hline Altitude above sea-level, in meters & & $\begin{array}{l}0.0016^{*} \\
(0.0009)\end{array}$ & $\begin{array}{l}0.0009 \\
(0.0009)\end{array}$ & $\begin{array}{l}0.0019 * * \\
(0.0010)\end{array}$ \\
\hline Surface area, in square kilometers & & $\begin{array}{l}0.0002 \\
(0.0039)\end{array}$ & $\begin{array}{l}0.0032 \\
(0.0037)\end{array}$ & $\begin{array}{l}0.0032 \\
(0.0037)\end{array}$ \\
\hline $\begin{array}{l}\text { Average of agricultural firms per } 100 \\
\text { inhabitants }\end{array}$ & & $\begin{array}{l}0.3806 * * * \\
(0.0928)\end{array}$ & $\begin{array}{l}0.2404 * * \\
(0.1105)\end{array}$ & $\begin{array}{l}0.1551 \\
(0.0948)\end{array}$ \\
\hline Share of commons & & $\begin{array}{l}-3.7645^{* * * *} \\
(1.3165)\end{array}$ & $\begin{array}{l}-3.5146^{* * * *} \\
(1.2771)\end{array}$ & $\begin{array}{l}-3.0139 * * \\
(1.2718)\end{array}$ \\
\hline Average of population, divided by 100 & & & $\begin{array}{l}-0.0037 \\
(0.0023)\end{array}$ & $\begin{array}{l}-0.0176^{* * * *} \\
(0.0051)\end{array}$ \\
\hline $\begin{array}{l}\text { Average of share of population aged } 65 \text { and } \\
\text { above }\end{array}$ & & & $\begin{array}{l}-8.8163 \\
(10.6531)\end{array}$ & $\begin{array}{l}-4.1647 \\
(9.7755)\end{array}$ \\
\hline $\begin{array}{l}\text { Average of share of German speaking } \\
\text { population }\end{array}$ & & & $\begin{array}{l}0.0001 \\
(0.0152)\end{array}$ & $\begin{array}{l}-0.0179^{*} \\
(0.0106)\end{array}$ \\
\hline Share of high school graduates & & & $\begin{array}{l}-0.2855^{* * * *} \\
(0.0967)\end{array}$ & $\begin{array}{l}-0.3243^{* * * *} \\
(0.0876)\end{array}$ \\
\hline Share of volunteers & & & $\begin{array}{l}4.0562 * * \\
(1.9035)\end{array}$ & $\begin{array}{l}2.5652 \\
(1.9245)\end{array}$ \\
\hline Average of number of hotel beds per capita & & & $\begin{array}{l}-0.3755 \\
(0.5209)\end{array}$ & $\begin{array}{l}-0.9677 * \\
(0.5017)\end{array}$ \\
\hline Income per capita, in logarithms & & & $\begin{array}{l}3.9656 \\
(2.4286)\end{array}$ & $\begin{array}{l}7.2569 * * * \\
(2.4338)\end{array}$ \\
\hline Constant & $\begin{array}{l}72.0983 * * * \\
(2.5680)\end{array}$ & $\begin{array}{l}70.6980 * * * \\
(2.4365)\end{array}$ & $\begin{array}{l}40.7700 * \\
(23.1913)\end{array}$ & $\begin{array}{l}25.5408 \\
(23.1240)\end{array}$ \\
\hline District-fixed effects included? & $x$ & $x$ & $x$ & $\checkmark$ \\
\hline Observations & 116 & 116 & 116 & 116 \\
\hline Lambda constant & $\begin{array}{l}0.0352 \\
(0.0332)\end{array}$ & $\begin{array}{l}0.0282 \\
(0.0301)\end{array}$ & $\begin{array}{l}0.0335 \\
(0.0283)\end{array}$ & $\begin{array}{l}0.0490^{*} \\
(0.0256)\end{array}$ \\
\hline Rho constant & $\begin{array}{l}0.6221 * * * \\
(0.0853)\end{array}$ & $\begin{array}{l}0.6531 * * * \\
(0.0844)\end{array}$ & $\begin{array}{l}0.6889 * * * \\
(0.0867)\end{array}$ & $\begin{array}{l}0.0553 \\
(0.2114)\end{array}$ \\
\hline Sigma squared constant & $\begin{array}{l}6.6650 * * * \\
(0.9004)\end{array}$ & $\begin{array}{l}5.2526^{* * * *} \\
(0.7131)\end{array}$ & $\begin{array}{l}4.3545 * * * \\
(0.5972)\end{array}$ & $\begin{array}{l}3.6588 * * * \\
(0.4807)\end{array}$ \\
\hline
\end{tabular}

Robust standard errors in brackets. *, **, *** indicate statistical significance at $10,5,1 \%$ level 


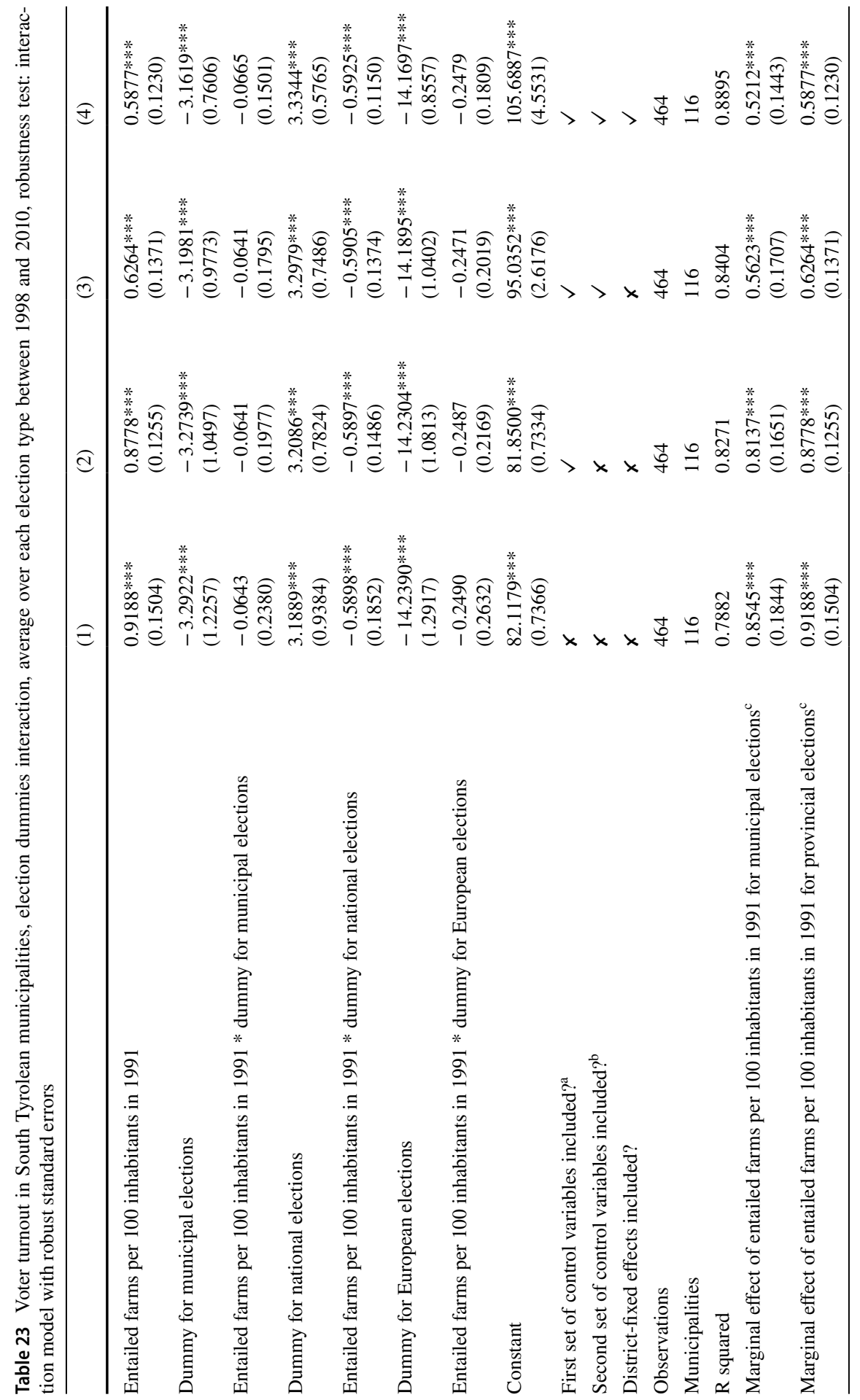




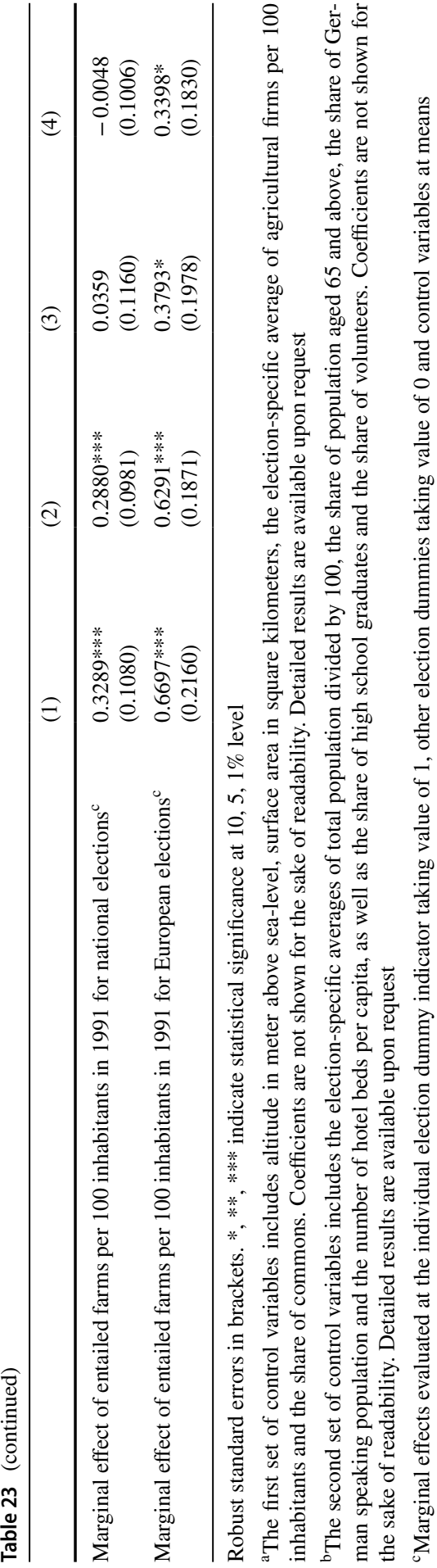




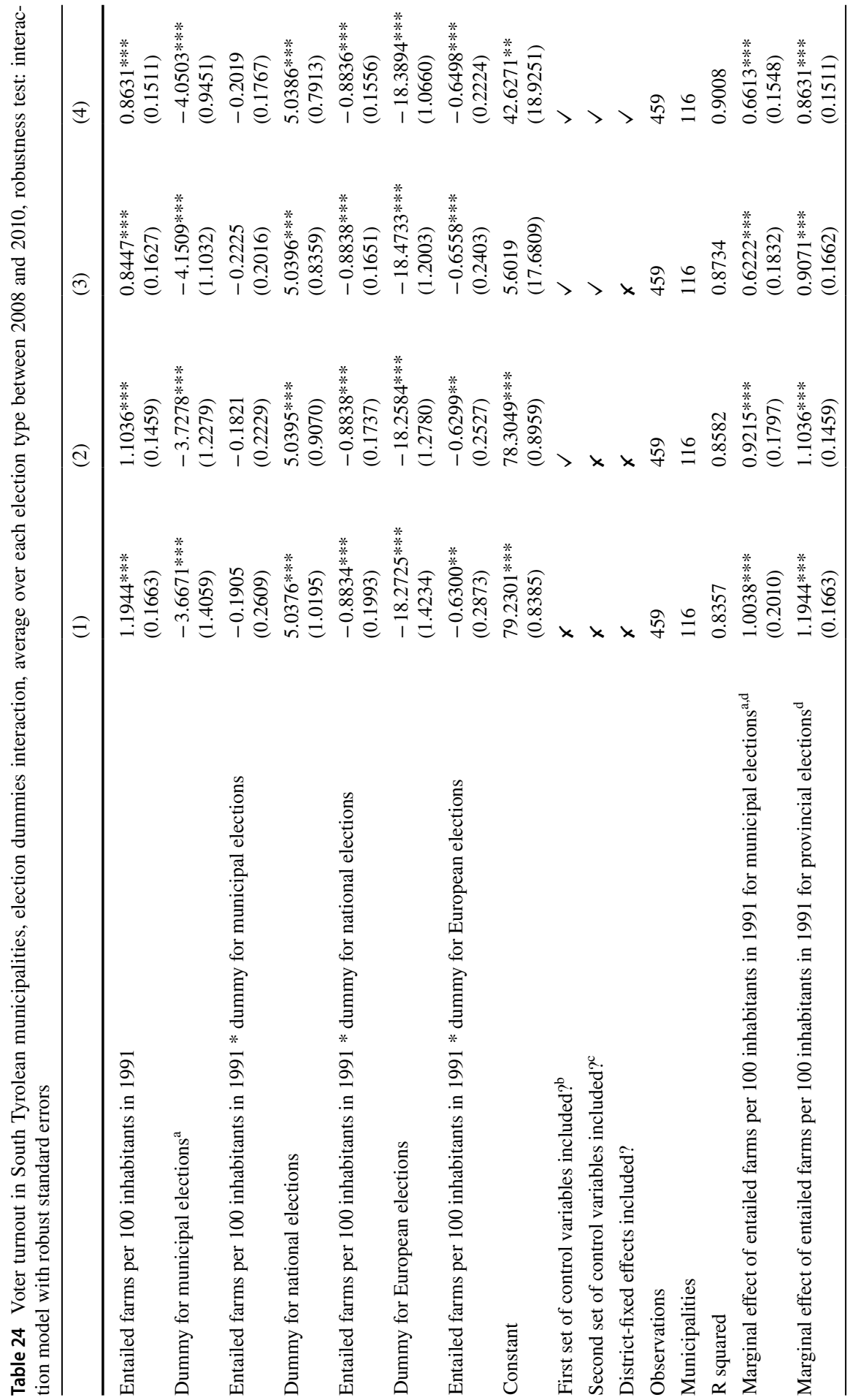




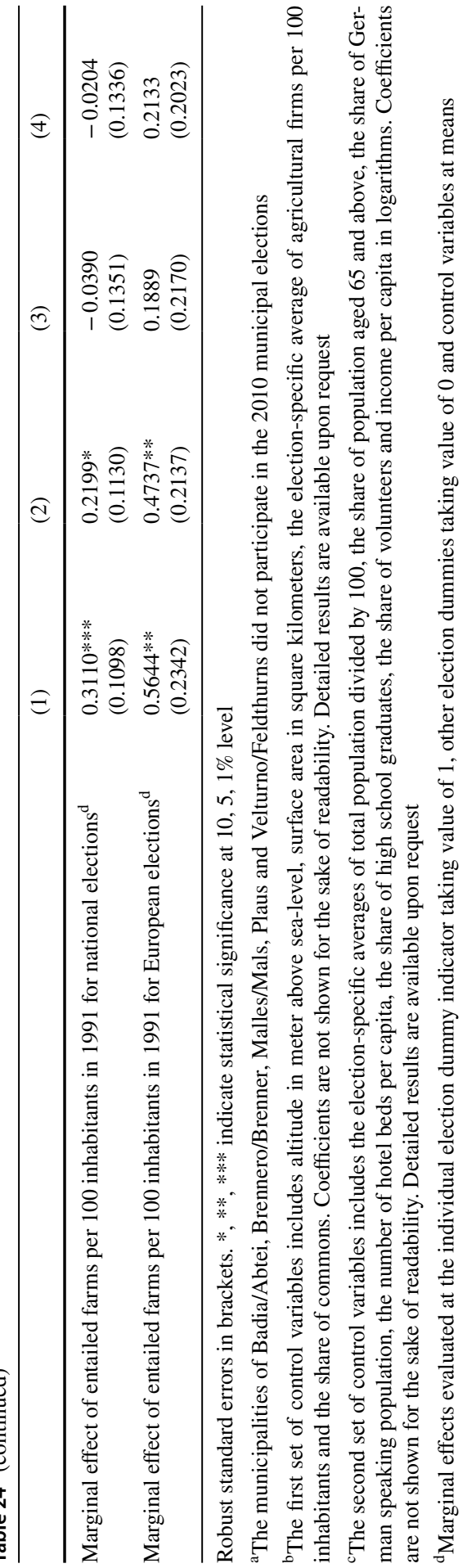




\section{References}

Agostini, D. (1962). Aspetti e problemi del “maso chiuso”. Padova: Cedam.

Alabrese, E., Becker, S. O., Fetzer, T., \& Novy, D. (2019). Who voted for Brexit? Individual and regional data combined. European Journal of Political Economy, 56, 132-150.

Aldrich, J. H. (1993). Rational choice and turnout. American Journal of Political Science, 37(1), 246-278.

Alesina, A., \& Giuliano, P. (2010). The power of family. Journal of Economic Growth, 15(2), 93-125.

Alesina, A., \& Giuliano, P. (2011). Family ties and political participation. Journal of the European Economic Association, 9(5), 817-839.

Artes, J. (2014). The rain in Spain: Turnout and partisan voting in Spanish elections. European Journal of Political Economy, 34, 126-141.

ASTAT. (2017). Dati Comunali, Istituto provinciale di statistica Alto Adige. Retrieved January 29, 2020, from http://qlikview.services.siag.it/QvAJAXZfc/opendoc.htm?document=gemeindeda tenblatt.qvw\&host=QVS\%40titan-a\&anonymous $=$ true.

Augschöll, A. (2004). La storia della scuola in Alto Adige. Bolzano: Alpha Beta.

Baker, M., \& Miceli, T. J. (2005). Land inheritance rules: Theory and cross-cultural analysis. Journal of Economic Behavior \& Organization, 56(1), 77-102.

Bätzing, W. (2003). Die Alpen. Geschichte und Zukunft einer europäischen Kulturladschaft. Munich: Beck.

Bechtel, M. M., Hangartner, D., \& Schmid, L. (2018). Compulsory voting, habit formation, and political participation. Review of Economics and Statistics, 100(3), 467-476.

Behrman, J. R., \& Rosenzweig, M. R. (2004). Parental allocations to children: New evidence on bequest differences among siblings. Review of Economics and Statistics, 86(2), 637-640.

Bisin, A., \& Verdier, T. (2001). The economics of cultural transmission and the dynamics of preferences. Journal of Economic Theory, 97(2), 298-319.

Bonoldi, A. (2009). A farewell to marginality. Development paths in the Italian Alpine Provinces since World War II. In A. Bonoldi \& A. Leonardi (Eds.), Recovery and development in the European periphery (1945-1960) (pp. 129-161). Berlin: Duncker \& Humblot.

Broms, R., \& Kokkonen, A. (2019). Inheritance regimes: Medieval family structures and current institutional quality. Governance, 32(4), 591-831.

Cancela, J., \& Geys, B. (2016). Explaining voter turnout: A meta-analysis of national and subnational elections. Electoral Studies, 42, 264-275.

Casari, M. (2007). Emergence of endogenous legal institutions: Property rights and community governance in the Italian Alps. Journal of Economic History, 67(1), 191-226.

Casari, M., \& Lisciandra, M. (2016). Gender discrimination in property rights: Six centuries of commons governance in the Alps. Journal of Economic History, 76(2), 559-594.

Cole, J. W., \& Wolf, E. R. (1974). The hidden frontier: Ecology and ethnicity in an Alpine Valley. New York: Academic Press.

Dehdari, S., \& Gehring, K. (2019). The origins of common identity: Evidence from Alsace-Lorraine. CESifo Working Paper No. 7949.

De Nardi, M. (2004). Wealth inequality and intergenerational links. Review of Economic Studies, 71(3), 743-768.

Dilli, S. (2016). Family systems and the historical roots of global gaps in democracy. Economic History of Developing Regions, 31(1), 82-135.

Downs, A. (1957). An economic theory of democracy. New York: Harper and Row.

Duranton, G., Rodriguez-Pose, A., \& Sandall, R. (2009). Family types and the persistence of regional disparities in Europe. Economic Geography, 85(1), 23-47.

Eurostat. (2017). Regional GDP, European Commission. Retrieved January 29, 2020, from http:// ec.europa.eu/eurostat/de/news/themes-in-the-spotlight/regional-gdp.

Francois, A., \& Gergaud, O. (2019). Is civic duty the solution to the paradox of voting? Public Choice, 180(3-4), 257-283.

Funk, P. (2010). Social incentives and voter turnout: Evidence from the Swiss Mail Ballot System. Journal of the European Economic Association, 8(5), 1077-1103.

Gaebler, S. (2020). Administrative areas and regional identity formation: The case of East Germany. Working Paper. 
Gaebler, S., Potrafke, N., \& Roesel, F. (2020). Compulsory voting and political participation: Empirical evidence from Austria. Regional Science and Urban Economics, 81, 103499.

Galasso, V., \& Profeta, P. (2018). When the state mirrors the family: The design of pension systems. Journal of the European Economic Association, 16(6), 1712-1763.

Garmann, S. (2017). The effect of a reduction in the opening hours of polling stations on turnout. Public Choice, 171(1), 99-117.

Gerber, A., Green, D. P., \& Larimer, C. W. (2008). Social pressure and voter turnout: Evidence from a large-scale field experiment. American Political Science Review, 102(1), 33-47.

Geys, B. (2006). 'Rational' theories of voter turnout: A review. Political Studies Review, 4(1), 16-35.

Gomez, B. T., Hansford, T. G., \& Krause, G. A. (2007). The Republicans should pray for rain: Weather, turnout, and voting in US presidential elections. Journal of Politics, 69(3), 649-663.

Grandits, H. (2003). Inheritance and social change in the decades of emancipation in the late Habsburg Empire: Some general trends. In H. Grandits \& P. Heady (Eds.), Distinct inheritances: Property, family and community in a changing Europe (pp. 207-227). Münster: LIT.

Grandits, H., \& Heady, P. (2003). Introduction: Property, family, and community in a changing Europe: A system and historical approach. In H. Grandits \& P. Heady (Eds.), Distinct inheritances: Property, family and community in a changing Europe (pp. 1-30). Münster: LIT.

Hamlin, A., \& Jennings, C. (2011). Expressive political behaviour: Foundations, scope and implications. British Journal of Political Science, 41(3), 645-670.

Hillman, A. L. (2010). Expressive behavior in economics and politics. European Journal of Political Economy, 26(4), 403-418.

Hillman, A. L., Metsuyanim, K., \& Potrafke, N. (2015). Democracy with group identity. European Journal of Political Economy, 40(4), 274-287.

Hoffman, M., Leon, G., \& Lombardi, M. (2017). Compulsory voting, turnout, and government spending: Evidence from Austria. Journal of Public Economics, 145, 103-115.

ISTAT. (2017). Branche dati e sistemi informativi, Istituto nazionale di statistica. Retrieved January 29, 2020, from http://www.istat.it/it/prodotti/banche-dati.

Jankowski, R. (2002). Buying a lottery ticket to help the poor: Altruism, civic duty and self-interest in the decision to vote. Rationality and Society, 14(1), 55-77.

Kofler, W. (1985). Land, Landschaft, Landtag. Geschichte der Tiroler Landtage von den Anfängen bis zur Aufhebung der landständischen Verfassung 1808. Innsbruck: Universitätsverlag Wagner.

Leonardi, A. (1996). L'economia di una regione alpine. Le trasformazioni economiche degli ultimi due secoli nell'area trentino-tirolese. Trento: Itas.

Leonardi, A. (Ed.). (2009). La Regione Trentino-Alto Adige/Südtirol nel XX secolo. Tomo 2: Economia. Trento: Fondazione Museo storico del Trentino.

Lind, J. T. (2019). Rainy day politics. An instrumental variables approach to the effect of parties on political outcomes. European Journal of Political Economy (forthcoming).

Martikainen, P., Martikainen, T., \& Wass, H. (2005). The effect of socioeconomic factors on voter turnout in Finland: A register-based study of 2.9 million voters. European Journal of Political Research, 44(5), 645-669.

Mori, E., \& Hintner, W. (2009). Der Geschlossene Hof: Geschichtliche Entwicklung und geltende Bestimmungen (1st ed.). Bolzano: Fondazione UPAD.

Mori, E., \& Hintner, W. (2013). Der Geschlossene Hof: Geschichtliche Entwicklung und geltende Bestimmungen (2nd ed.). Bolzano: Fondazione UPAD.

Poggeschi, G. (2008). South Tyrol's special status in private law: The entailed farm and the 'Grundbuch' systems. In J. Woelk, F. Palermo, \& J. Marko (Eds.), Tolerance through law. Self Governance and Group Rights in South Tyrol (pp. 291-301). Leiden: Martinus Nijhoff Publishers.

Poggeschi, G., \& Lantschner, E. (2008). Quota system, census and declaration of affiliation to linguistic group. In J. Woelk, F. Palermo, \& J. Marko (Eds.), Tolerance through law. Self Governance and Group Rights in South Tyrol (pp. 219-233). Leiden: Martinus Nijhoff Publishers.

Potrafke, N., \& Roesel, F. (2019). A banana republic? The effects of inconsistencies in the counting of votes on voting behavior. Public Choice, 178(1-2), 231-265.

Potrafke, N., \& Roesel, F. (2020). Opening hours of polling stations and voter turnout: Evidence from a natural experiment. Review of International Organizations, 15(1), 133-163.

Provincia Autonoma di Bolzano Alto Adige (1997). Part IX Articles 107 \& 108. In Landesraumordnungsgesetz 13. Bolzano: Provincia Autonoma di Bolzano Alto Adige.

Ricardo, D. (1821). On the principles of political economy and taxation. London: John Murray. 
Schelker, M., \& Schneiter, M. (2017). The elasticity of voter turnout: Investing 85 cents per voter to increase voter turnout by 4 percent. Electoral Studies, 49, 65-74.

Schennach, M. (2003). Geschichte des bäuerlichen Besitz- und Erbrechtes in Tirol - ein Überblick. In M. Schennach (Ed.), Hofgeschichten der 2002 und 2003 verliehenen Erbhöfe (Tiroler Erbhöfe Nr. 21), 9-30. Innsbruck: Tiroler Landesarchiv.

Schuessler, A. A. (2000). Expressive voting. Rationality and Society, 12(1), 87-119.

Schuler, E. (1992). Il maso chiuso: Effetti sulla geografia di un territorio. University of Verona, unpublished manuscript.

Settis, S. (2012). Paesaggi, costituzione e cemento. Torino: Einaudi.

Steininger, R. (2003). South Tyrol. A minority conflict of the twentieth century. London: Transaction Publishers.

Sundström, A., \& Stockemer, D. (2015). Voter turnout in the European regions: The impact of corruption perceptions. Electoral Studies, 40, 158-169.

Todd, E. (1990). L'invention de l'Europe. Paris: Seuil.

Vogel, S., Larcher, M., Maurer, O., \& Wytrzens, H. K. (2009). Perceptions of non-commodity functions of mountain farming in South Tyrol: A report on survey results. In H. Peyerl (Ed.), Jahrbuch der Österreichischen Gesellschaft für Agrarökonomie (pp. 141-149). Wien: Facultas.

Vogel, S., Maurer, O., Wytrzens, H. K., \& Larcher, M. (2007). Perceptions of mountain farming in South Tyrol: Cultural differences in a border region. In J. Kabrda, J. \& I. Bicik (Eds.), Man in the landscape across Frontiers: Landscape and land use change in central European border regions. Conference proceedings of the IGU/LUCC central Europe conference (pp. 209-220).

Publisher's Note Springer Nature remains neutral with regard to jurisdictional claims in published maps and institutional affiliations. 